\title{
Nicotine Regulates Multiple Synaptic Proteins by Inhibiting Proteasomal Activity
}

\author{
Khosrow Rezvani, ${ }^{1}$ Yanfen Teng, ${ }^{1}$ David Shim, ${ }^{1}$ and Mariella De Biasi ${ }^{1,2,3}$ \\ Departments of ${ }^{1}$ Neuroscience and ${ }^{2}$ Molecular Physiology and Biophysics and ${ }^{3}$ Graduate Program in Translational Biology and Molecular Medicine, Baylor \\ College of Medicine, Houston, Texas 77030
}

\begin{abstract}
Ubiquitination regulates the degradation, membrane trafficking, and transcription of proteins. At mammalian synapses, the ubiquitinproteasome system (UPS) influences synaptic transmission and plasticity. Nicotine also has the ability to affect synaptic function via mechanisms that remain partially unknown. We found that nicotine, at concentrations achieved by smokers, reduced proteasomal activity, produced accumulation of ubiquitinated synaptic proteins, and increased total protein levels. In particular, a $24 \mathrm{~h}$ exposure to nicotine decreased proteasome-dependent degradation of the $\alpha 7$ nicotinic acetylcholine receptor (nAChR) subunit, as indicated by the accumulation of ubiquitinated $\alpha 7$. The same nicotine treatment increased the levels of the AMPA glutamate receptor subunit GluR1, the NMDA receptor subunit NR2A, the metabotropic receptor $\operatorname{mGluR} 1 \alpha$, the plasticity factor Homer-1A, and the scaffolding postsynaptic density protein PSD-95, whereas the levels of another scaffolding protein, Shank, were reduced. These changes were associated with an inhibition of proteasomal chymotrypsin-like activity by nicotine. The nAChR antagonist mecamylamine was only partially able to block the effects of nicotine on the UPS, indicating that nAChR activation does not completely explain nicotine-induced inhibition of proteasomal catalytic activity. A competition binding assay suggested a direct interaction between nicotine and the $20 \mathrm{~S}$ proteasome. These results suggest that the UPS might participate in nicotine-dependent synaptic plasticity.
\end{abstract}

Key words: nicotine; nicotinic acetylcholine receptor; proteasome; ubiquitin; glutamate receptors; mecamylamine

\section{Introduction}

Ubiquitin is a highly conserved polypeptide that is covalently linked to proteins (Glickman and Ciechanover, 2002). The addition of single ubiquitin moieties influences protein trafficking between cellular compartments, whereas the addition of multiple ubiquitins targets proteins for degradation by the proteasome complex. The ubiquitin-proteasome system (UPS), by regulating protein degradation, is also involved in the development and function of the synapse (Yi and Ehlers, 2007). Changes in UPS activity may either promote or suppress synaptic plasticity. For example, the UPS controls the changes in protein levels of glutamate receptors, scaffolding and adaptor proteins, and signaling enzymes that characterize the activity-dependent reorganization of the synapse (Yi and Ehlers, 2007).

Nicotine produces neural adaptations that change behavior and whole-body physiology during nicotine dependence. The actions of nicotine depend on the anatomical distribution and the cellular localization of nicotinic acetylcholine receptors (nAChRs) and are attributable to the influence on various cellular processes and intracellular pathways. Enhancement of neuro-

Received Jan. 29, 2007; revised Aug. 13, 2007; accepted Aug. 13, 2007.

This work was supported in part by National Institute on Drug Abuse Grant DA017173, the Whitaker Foundation, and Philip Morris USA and Philip Morris International (M.D.B.). We thank Drs. J. R. Mayer, G. N. DeMartino, and J. A. Dani for insightful suggestions; Dang Dao for the help with the illustrations; and Adam Main, Sanam Sane, and Shelly A. Buffington for excellent technical support.

Correspondence should be addressed to Mariella De Biasi, Department of Neuroscience, Baylor College of Medicine, Houston, TX 77030. E-mail: debiasi@bcm.tmc.edu.

D01:10.1523/JNEUROSCI.3353-07.2007

Copyright $\odot 2007$ Society for Neuroscience $\quad$ 0270-6474/07/2710508-12\$15.00/0 transmitter release via presynaptic nAChR activation is a well established effect of nicotine (Dajas-Bailador and Wonnacott, 2004), but postsynaptic nAChRs can also contribute to synaptic potentiation when their activation coincides with weak presynaptic stimulation (Ji et al., 2001). By enhancing neurotransmitter release, nicotine can induce NMDA receptor-dependent longterm potentiation (LTP) (Mansvelder and McGehee, 2000), which might contribute to the cellular adaptations that the drug produces (Jones and Bonci, 2005).

nAChR upregulation is another phenomenon that might contribute to the addictive properties of nicotine. The density of $\beta 2$ and $\alpha 7$-containing nAChRs is increased after chronic exposure to nicotine both in vivo and in vitro (Gaimarri et al., 2007), but how their upregulation is achieved is not clear. Among the potential mechanisms are receptor desensitization (Fenster et al., 1999b), decreased surface receptor turnover (Peng et al., 1997), and isomerization of surface $\mathrm{nAChRs}$ to high-affinity nicotinic sites (Buisson and Bertrand, 2002; Vallejo et al., 2005). Alternatively, nicotine might promote intracellular receptor subunit assembly in the endoplasmic reticulum (ER) (Christianson and Green, 2004; Darsow et al., 2005; Sallette et al., 2005). Nicotine-induced adaptations may derive also from the activation of intracellular pathways that modulate the levels of other proteins (DajasBailador and Wonnacott, 2004). For example, nicotine modulates mRNA and protein expression levels of genes involved in glutamatergic transmission. Nicotine increases mRNA and/or protein levels of AMPA and NMDA receptors (Ferrari et al., 2002; Wang et al., 2007) and upregulates protein levels of group I 
metabotropic glutamate receptors (mGluRs) and members of the Homer family of proteins (Kane et al., 2005). In particular, the literature reports increased levels of GluR1, NMDA receptor subunit NR2A, and mGluR1 $\alpha$ (Kane et al., 2005; Wang et al., 2007).

Because the UPS regulates the turnover of nicotinic receptors and glutamate receptors (Christianson and Green, 2004; Gaimarri et al., 2007; Yi and Ehlers, 2007), we investigated the nicotine/ UPS interaction as a potential mechanism for nicotine-induced changes in nicotinic and glutamate receptor densities. We show that nicotine acts as a partial proteasome inhibitor and propose the modulation of proteasomal activity as one of the mechanisms through which nicotine can affect the synapse.

\section{Materials and Methods}

Antibodies. Polyclonal anti- $\alpha 7 \mathrm{nAChR}$ subunit (H-302; 1:500 dilution) (supplemental Fig. 4, available at www.jneurosci.org as supplemental material), rabbit polyclonal anti-actin (H-196; 1:1000 dilution), goat anti-mouse (1:2500), and mouse anti-rabbit secondary (1:2500) antibodies were purchased from Santa Cruz Biotechnology (Santa Cruz, CA). Mouse monoclonal anti-Tyg raised against the extended synthetic peptide EVHTNQDPLD (Brookman et al., 1995) was a gift from Dr. John Mayer (University of Nottingham, Nottingham, UK) (1:1000). Mouse monoclonal antiserum against the $19 \mathrm{~S}$ regulator ATPase subunit Rpt6/S8 (clone p45-110; 1:1000) was purchased from Biomol (Plymouth Meeting, PA). Polyclonal anti-proteasome activator PA700 subunit 10B was purchased from Calbiochem (San Diego, CA) (1:1000). Polyclonal anti-20S proteasome core subunit was a generous gift from Dr. George N. DeMartino (Department of Physiology, University of Texas, Southwestern Medical Center, Dallas, TX) (1:1000). Mouse monoclonal antipostsynaptic density 95 (PSD-95) (clone K28/43; 1:1000) and rabbit polyclonal anti-GluR1 were purchased from Upstate (Charlottesville, VA) (1:1000). Rabbit polyclonal anti-metabotropic glutamate receptor $1 \alpha$ was purchased from Affinity BioReagents (Golden, CO) (1:1000). Rabbit polyclonal anti-NR2A was purchased from Tocris Bioscience (Ellisville, MO) (1:1000). Mouse monoclonal anti-glyceraldehyde 3-phosphate dehydrogenase (GAPDH) $(1: 40,000)$ was purchased from Chemicon (Temecula, CA). Anti-Shank polyclonal antibodies were a generous gift from Dr. Paul F. Worley (Department of Neurosciences, The Johns Hopkins University School of Medicine, Baltimore, MD) (1: 5000). Anti-ubiquitin was purchased from Cell Signaling Technology (Danvers, MA) (1:2500). SuperSignal West Femto (Pierce, Rockford, IL) or Immobilon Western chemiluminescent-horseradish peroxidase (HRP; Millipore, Billerica, MA) were used for chemiluminescent detection of proteins.

Mammalian expression constructs. The Homer-1A construct was a gift from Dr. John Mayer. To create Homer-1A with an N-terminal $6 \times$ histidine and a Tyg tag [(His) ${ }_{6}$-Tyg], the full-length Homer-1A coding region DNA was inserted in-frame at the $\mathrm{C}$ terminus of (His) ${ }_{6}$-Tyg in pcDNA3.1 Zeo + vector (Invitrogen, Carlsbad, CA). This vector was modified by adding $6 \times$ histidine and an extended Tyg sequence (EVHTNQDPLD) downstream of the cytomegalovirus promoter of the vector with a NotI restriction site in-frame created after (His) ${ }_{6}$-Tyg.

Animals, nicotine administration, and brain slices. Male C57BL/6J mice $(250-350 \mathrm{~g})$ received either saline or nicotine at a dose of 0.5 $\mathrm{mg} / \mathrm{kg}$ in saline every $6 \mathrm{~h}$ intraperitoneally for a total of $24 \mathrm{~h}$. Two hours after the fifth injection, mice were decapitated under anesthesia with a mixture of xylazine, acepromazine, and ketamine, and the brains were removed immediately for sectioning. Four millimeters of the frontal cortex were cut in ice-cold PBS, using an acrylic matrix (World Precision Instruments, Sarasota, FL). Tissue homogenization was performed in $500 \mu \mathrm{l}$ of ice-cold homogenization buffer $(0.32 \mathrm{M}$ sucrose, $10 \mathrm{~mm}$ HEPES, and $2 \mathrm{~mm}$ EDTA, $\mathrm{pH}$ 7.4) containing a protease inhibitor cocktail (Sigma, St. Louis, MO). Homogenized tissues were solubilized by either adding Triton X-100 at $4^{\circ} \mathrm{C}$ for $1 \mathrm{~h}$ for protein analysis or repeated freeze/thaw in liquid nitrogen for enzyme analysis. To better assess the $26 \mathrm{~S}$ proteasome, tissue homogenization was performed in $500 \mu \mathrm{l}$ of ice-cold modified homogenization buffer (0.32 м sucrose, 10 mM HEPES buffer, pH 7.4, 2 mm EDTA, $1 \mathrm{~mm}$
ATP, and $5 \mathrm{~mm} \mathrm{MgCl}_{2}$ ). Homogenized tissues were solubilized by repeated freeze/thaw. Supernatants were analyzed by Western blotting or were subjected to glycerol gradient fractionation as described below. All procedures were approved by the Institutional Animal Care and Use Committee in accordance with federal guidelines.

Tissue culture and degradation assays. Human embryonic kidney HEK-293 cells were grown at $37^{\circ} \mathrm{C}$ and $5 \% \mathrm{CO}_{2}$ in DMEM (Invitrogen) supplemented with $1 \mathrm{~mm}$ sodium pyruvate, $2 \mathrm{~mm}$ L-glutamine, and $10 \%(\mathrm{v} / \mathrm{v})$ fetal bovine serum (FBS). Cells were passaged when $60-80 \%$ confluent. For transient expression, HEK-293 cells growing in $100 \mathrm{~mm}$ dishes were transfected with Homer-1A cDNA by calcium phosphate precipitation. PC12 cells were obtained from the American Type Culture Collection (Rockville, MD) and propagated by serial passage. PC12 cells were grown in F-12 Kaighn's modified medium (HyClone, Logan, UT) supplemented with 10\% horse serum and 5\% FBS. Serial propagation of all cell lines was limited to 15 passages after thawing. PC12 cells were differentiated with $100 \mathrm{ng} / \mathrm{ml}$ nerve growth factor-7S from murine submaxillary gland (Sigma). Cells were seeded on $100 \mathrm{~mm}$ collagen-coated plates at a density of $5-10 \times 10^{5} \mathrm{cells} / \mathrm{ml}$ media for $\sim 7-10 \mathrm{~d}$ before cell treatment. The effects of nicotine on protein degradation were measured in HEK-293 cells or differentiated PC12 cells. Equal numbers of cells were incubated for $24 \mathrm{~h}$ at $37^{\circ} \mathrm{C}$ on $100 \mathrm{~mm}$ plates in $5 \% \mathrm{CO}_{2}$ along with the proteasome inhibitor MG132 (carbobenzoxy-L-leucyl-L-leucyl-L-leucinal) (10 $\mu \mathrm{M}$; Biomol) or (-)nicotine hydrogen tartrate (300 or $500 \mathrm{~nm}$ as free base; Sigma) in the presence of emetine (150 $\mu$; Calbiochem).

For protein assays, cells were harvested in buffer A (in тм: 50 $\mathrm{Na}_{2} \mathrm{HPO}_{4} \cdot \mathrm{NaH}_{2} \mathrm{PO}_{4}, \mathrm{pH} 7.5,50 \mathrm{NaCl}, 5$ EDTA, 5 EGTA, 5 benzamidine, 15 iodoacetamide, and 2 phenylmethylsulfonyl fluoride) and pelleted by centrifugation. The pellets were rinsed three times with buffer A before adding buffer B (buffer A plus 3\% Triton X-100). Samples were incubated at $4^{\circ} \mathrm{C}$ for $1 \mathrm{~h}$, followed by centrifugation at $14,000 \mathrm{rpm}$ for $15 \mathrm{~min}$ in a refrigerated bench-top centrifuge. All cell extracts were subjected to Western blot analysis after protein concentrations were determined with a BCA Protein Assay kit (Pierce).

For enzyme assays, cells were pelleted by centrifugation. The pellets were rinsed three times with PBS, pH 7.4, before addition of lysis buffer [20 mm Tris- $\mathrm{HCl}$, pH 7.2 buffer; $1 \mathrm{ml} / 100 \mathrm{~mm}$ plate) containing EDTA ( $1 \mathrm{~mm}), \mathrm{NaN}_{3}(1 \mathrm{~mm}), \beta$-mercaptoethanol $(1 \mathrm{~mm}), \mathrm{NP}-40(0.1 \% \mathrm{v} / \mathrm{v})$, glycerol $(10 \% \mathrm{v} / \mathrm{v})$, and protease inhibitor cocktail (Sigma)]. Cell extracts were prepared by repeated freeze/thaw in liquid nitrogen. Extracts were centrifuged for $15 \mathrm{~min}$ at 14,000 rpm as mentioned before. All cell extracts were subjected to Western blot analysis or glycerol gradient fractionation after protein concentrations were determined with a BCA Protein Assay kit (Pierce).

Pull-down assays. Pull-down assays were conducted with the agaroseimmobilized p62-derived UBA domain (Biomol). Equal amounts of protein were incubated overnight at $4^{\circ} \mathrm{C}$ with $25 \mu \mathrm{l}$ of beads chemically coupled to the UBA domain. Beads were washed four times with cold PBS, and the supernatants were discarded. Proteins were eluted in SDSPAGE sample $(2 \times)$ buffer and incubated at $80^{\circ} \mathrm{C}$ for $3 \mathrm{~min}$. Each eluted sample was loaded onto a spin filter (Cytosignal, Irvine, CA) and spun to remove the beads. The protein samples $(20 \mu \mathrm{l})$ were then subjected to SDS-PAGE and Western blot analysis. Detection of coprecipitants was accomplished with specific antibodies.

Glycerol gradient fractionation. For samples not supplemented with ATP, equal amounts of proteins were loaded onto $10-40 \%(\mathrm{v} / \mathrm{v})$ glycerol gradients, and columns were centrifuged at $70,000 \times g$ for $22 \mathrm{~h}$ at $4^{\circ} \mathrm{C}$. Twenty-one or twenty-two sequential, equal-volume fractions $(500 \mu \mathrm{l})$ were collected from the bottom of the tube with a Labconco (Kansas City, MO) Auto Densi-flow gradient collector and analyzed by Western blotting or assayed for chymotrypsin-like activity as described below. For samples supplemented with ATP, equal amounts of protein were loaded onto $10-40 \%(\mathrm{v} / \mathrm{v})$ glycerol gradients containing $50 \mathrm{~mm}$ Tris- $\mathrm{HCl}, \mathrm{pH}$ 7.6, $1 \mathrm{~mm} \mathrm{DTT,} 5 \mathrm{~mm} \mathrm{MgCl}_{2}$, and $1 \mathrm{~mm} \mathrm{ATP}$, and columns were centrifuged at $200,000 \times g$ for $4.5 \mathrm{~h}$ at $4^{\circ} \mathrm{C}$. Fifteen sequential, equal-volume fractions $(250 \mu \mathrm{l})$ were collected from the bottom of the tube and analyzed by Western blotting or assayed for chymotrypsin-like activity as described below. 
Measurements of chymotrypsin-like activity. The catalytic activity of $20 \mathrm{~S}$ or $26 \mathrm{~S}$ proteasome was assessed by fluorescence of free 7 -amino4-methylcoumarin (AMC) (excitation, $360 \mathrm{~nm}$; emission, $460 \mathrm{~nm}$ ) liberated from a substrate peptide (succinyl-Leu-Leu-Val-Tyr-AMC; Biomol). After glycerol gradient fractionation, $20 \mu$ l aliquots were incubated at $37^{\circ} \mathrm{C}$ for $1 \mathrm{~h}$ in the presence of $10 \mu \mathrm{M}$ substrate peptide, followed by quenching with $2 \mathrm{ml}$ of cold $80 \mathrm{~mm}$ sodium acetate, $\mathrm{pH}$ 4.5. For in vitro $20 \mathrm{~S}$ chymotrypsin-like activity, $20 \mathrm{~S}$ proteasomes $\mathrm{pu}-$ rified from human erythrocytes (100 ng/ $\mu \mathrm{l}$; Biomol), the substrate peptide $(10 \mu \mathrm{M})$, and nicotine (300 or $500 \mathrm{~nm})$ or MG132 (10 $\mu \mathrm{M})$, were combined in assay buffer (in mм: 50 Tris, pH 7.5, $25 \mathrm{KCl}, 10$ $\mathrm{NaCl}$, and $1 \mathrm{MgCl}_{2}$ ). For in vitro $26 \mathrm{~S}$ chymotrypsin-like activity, $26 \mathrm{~S}$ proteasome from human erythrocytes (Biomol) was diluted to 9 $\mathrm{ng} / \mu \mathrm{l}$ in enzyme buffer (50 mм HEPES, pH 7.6, $150 \mathrm{~mm} \mathrm{NaCl}, 2 \mathrm{~mm}$ ATP, $1.1 \mathrm{~mm} \mathrm{MgCl}_{2}$, and $10 \%$ glycerol) and combined with the substrate peptide $(10 \mu \mathrm{M})$ and either nicotine (300 or $500 \mathrm{~nm}$ ) or MG132 $(10 \mu \mathrm{M})$ dissolved in substrate buffer (50 mM HEPES, pH 7.6, $150 \mathrm{~mm}$ $\mathrm{NaCl}, 5 \mathrm{~mm} \mathrm{MgCl}_{2}$, and $10 \%$ glycerol) at the indicated final concentrations. Both reactions were incubated at $37^{\circ} \mathrm{C}$ for $1 \mathrm{~h}$ and then stopped with $200 \mu \mathrm{l}$ of cold $80 \mathrm{~mm}$ sodium acetate, $\mathrm{pH}$ 4.5. In other experiments (see Fig. 6b), chymotrypsin-like activity was measured in prefrontal cortex (PFC) crude extracts according to Kisselev and Goldberg (2005). All fluorescence measurements were read using an SLM-Aminco spectrofluorometer (Horiba Jobin Yvon, Edison, NJ). AMC fluorescence liberated in the absence of drugs was taken as $100 \%$.

Deubiquitination assay. Cell lysates were prepared from HEK-293 cells treated with vehicle or $500 \mathrm{~nm}$ nicotine for $24 \mathrm{~h}$. Equal amount of cell lysates were incubated with p62-beads overnight at $4^{\circ} \mathrm{C}$. After washing, p62 beads were resuspended in 25 mM HEPES, pH 7.4, and 10 mM DTT, followed by incubation with $5 \mu \mathrm{g}$ each of isopeptidase-T (Calbiochem) and UCH-L3 (Biomol) for $60 \mathrm{~min}$ at room temperature (RT). P62 beads were then centrifuged and eluted by boiling in SDS-PAGE sample buffer $(2 \times)$, followed by SDS-PAGE and transfer to nitrocellulose membranes. Membranes were then probed with anti-ubiquitin antibodies.

Binding assay of $\left[{ }^{3} \mathrm{H}\right]$ nicotine to proteasome. Partially purified proteasomes from HEK-293 cells were prepared as described previously (Kisselev and Goldberg, 2005). We incubated $20 \mu \mathrm{g}$ of purified proteasomes in binding buffer (in mM: 50 Tris- $\mathrm{HCl}, \mathrm{pH} 7.5,25 \mathrm{KCl}, 10 \mathrm{NaCl}$, and $1 \mathrm{MgCl}_{2}$ ) with or without nicotine $(10 \mathrm{~mm})$ for $30 \mathrm{~min}$ at $37^{\circ} \mathrm{C}$. Subsequently, $1 \mu \mathrm{M}\left[{ }^{3} \mathrm{H}\right]$ nicotine $(66.9 \mathrm{Ci} / \mathrm{mmol})$ was added to each sample, followed by another $30 \mathrm{~min}$ incubation at $37^{\circ} \mathrm{C}$. To determine the level of nonspecific binding of $\left[{ }^{3} \mathrm{H}\right]$ nicotine to the filter, the same experiment was set up in the absence of proteasomes. Incubations were terminated by filtration through a polyethersulfone filter, using a microsep centrifugal device with a $10 \mathrm{kDa}$ molecular weight cutoff (Pall, Ann Arbor, MI). The filters were washed three times with ice-cold binding buffer $(3.5 \mathrm{ml})$ by spinning at $7500 \times g$ for $25 \mathrm{~min}$, and the filtratecollected samples were transferred to scintillation insert vials containing $5.0 \mathrm{ml}$ pf scintillator (National Diagnostics, Atlanta, GA). After $1 \mathrm{~h}$ incubation at RT, the samples were counted in a scintillation counter (LS 6500; Beckman Coulter, Fullerton, CA).

Detection of $\alpha$ bungarotoxin-binding sites in brain homogenates. C57BL/6J male mice received intraperitoneal injections of saline or nicotine $(0.5 \mathrm{mg} / \mathrm{kg})$ as described previously. Two hours after the last injection, PFCs were removed and proteins were extracted using sonication, followed by repeated freezing and thawing and centrifugation. Proteins were separated on $7.5 \%$ SDS-PAGE gels, followed by blotting onto nitrocellulose membranes and incubation for $20 \mathrm{~h}$ at $4^{\circ} \mathrm{C}$ with $5 \mu \mathrm{g} / \mathrm{ml}$ biotinconjugated $\alpha$-bungarotoxin (biotin-XX conjugate; Invitrogen). After washing, membranes were treated with streptavidin-conjugated HRP (Invitrogen) in TBST (TBS plus $0.1 \%$ Tween 20 ) plus $1 \%$ dry milk (1: 4000 ) at RT. After washing with TBST (three times for 5 min) and TBS (one time for $5 \mathrm{~min}$ ), $\alpha$-bungarotoxin binding sites were visualized by chemiluminescence (Millipore).

Preparation of brain membrane fractions. To isolate membrane fractions, we followed a method described by Gurd et al. (1974). PFCs were dissected and transferred into $10 \mathrm{vol}$ of cold homogenization buffer $(0.32 \mathrm{~m}$ sucrose, $10 \mathrm{~mm}$ HEPES, pH 7.4, 2 mM EDTA, and protease inhibitor cocktail). A motor-driven homogenizer was used to homogenize the tissue, followed by centrifugation at $1000 \times g$ for $15 \mathrm{~min}$ to remove the pelleted nuclear fraction (P1). The supernatant (S1) was taken and spun at 200,000 $\times g(54,800 \mathrm{rpm}$ for $15 \mathrm{~min}$ in TLS-55 rotor; Beckmann Coulter) to yield crude cytosol (S2) and crude membrane pellets (P2). Pellets were resuspended in homogenization buffer and centrifuged at 200,000 $\times g$ to yield washed crude membrane pellets $\left(\mathrm{P}^{\prime}\right)$. $\mathrm{P} 2$ ' pellets were resuspended in HEPES-lysis buffer (50 mM HEPES, pH 7.4, 2 mM EDTA, and protease inhibitor cocktail), and the protein concentration was measured by BCA. All procedures were performed with precooled reagents at $4^{\circ} \mathrm{C}$. The membrane fraction was solubilized with $3 \%$ Triton $\mathrm{X}-100$ at $4^{\circ} \mathrm{C}$ for $2 \mathrm{~h}$, followed by Western blot analysis using anti- $\alpha 7 \mathrm{nAChRs}$ antibodies (clone H-302, 1:500; Santa Cruz Biotechnology).

To test the specificity of the anti- $\alpha 7$ antibodies, PFCs from three homozygous $\alpha 7$ null $(-/-)$ mice and three littermate control $(+/+)$ mice were mechanically homogenized in $500 \mu \mathrm{l}$ of ice-cold homogenization buffer. Proteins were extracted using sonication, followed by repeated freezing and thawing. The solubilized protein supernatant was recovered after centrifugation at $14,000 \mathrm{rpm}$ for $15 \mathrm{~min}$. After determining protein concentrations by BCA assay (Pierce), solubilized proteins ( $3.6 \mathrm{mg}$ ) were incubated overnight with $12 \mu \mathrm{l}$ of biotin-conjugated $\alpha$-bungarotoxin (biotin-XX, $1 \mu \mathrm{g} / \mu \mathrm{l}$; Invitrogen), followed by loading into a column containing immobilized NeutrAvidin (Pierce). After washing, bound nAChRs were eluted with SDS/sample buffer and separated by SDSPAGE, followed by transfer to a nitrocellulose membrane. After overnight incubation at $4^{\circ} \mathrm{C}$ with the anti- $\alpha 7$ polyclonal rabbit antibody (1: 500; Santa Cruz Biotechnology), the membrane was washed and probed with goat-anti rabbit-HRP at a dilution of 1:2500. After washing the membranes with TBS plus $0.1 \%$ Tween $20(\mathrm{v} / \mathrm{v}), \alpha 7$ was detected with SuperSignal West Femto (Pierce).

Densitometric quantification of Western blot bands. Quantification of the intensity of Western blot bands was carried by using the UNSCAN-IT gel automated digitizing system (Silk Scientific, Orem, UT). Developed films were scanned as a JPEG file (.jpg) in eight-bit grayscale format at 600 dpi setting. The pixel intensities within a band were measured using the segment analysis selection in the software. The pixel intensities was corrected for background. After exporting into Excel (Microsoft, Seattle, WA), the digitized gel data (pixel total) were used to calculate the relative optical densities gel bands for additional analysis.

Statistics. Group differences were assessed by one-way ANOVA according to the homogeneity of variances or by unpaired Student's $t$ test. Post hoc analysis was conducted using the Newman-Keuls or Dunn's comparisons. All data are reported as mean \pm SEM.

\section{Results}

Nicotine treatment increases protein levels of $\alpha 7 \mathrm{nAChRs}$ and glutamate receptors in the prefrontal cortex

To investigate the effects of nicotine on the protein levels of $\alpha 7$ $\mathrm{nAChRs}$ and glutamate receptors, we injected male C57BL/6J mice intraperitoneally every $6 \mathrm{~h}$ for $24 \mathrm{~h}$ with either saline or 0.5 $\mathrm{mg} / \mathrm{kg}$ nicotine. These nicotine doses achieve plasma concentrations of $\sim 400 \mathrm{nM}$ (Davis et al., 2005), which are comparable with the levels of nicotine found in smokers (Benowitz et al., 1982; Jarvik et al., 2000). Mice were killed $2 \mathrm{~h}$ after the last nicotine injection, and PFC tissue lysates were subjected to Western blot analysis to compare protein levels in saline- versus nicotinetreated mice (Fig. 1). Our analysis revealed that the protein levels of the $\alpha 7 \mathrm{nAChR}$ subunit were almost 29\% higher after nicotine exposure (Fig. 1a, left; eight saline- vs nine nicotine-treated mice; $p=0.0013)$. The increase in $\alpha 7$ levels was confirmed by detecting the subunit with biotinylated $\alpha$-bungarotoxin, a toxin known to selectively bind to $\alpha 7$-containing nAChRs, followed by exposure to horseradish peroxidase-conjugated streptavidin (Fig. 1a, right; $54 \%$ increase; eight control mice vs nine nicotine-treated mice; $p=0.007$ ). The heavier band in Figure $1 a$ likely represents the glycosylated (fully mature) form of $\alpha 7$ versus the nonglycosylated 
a

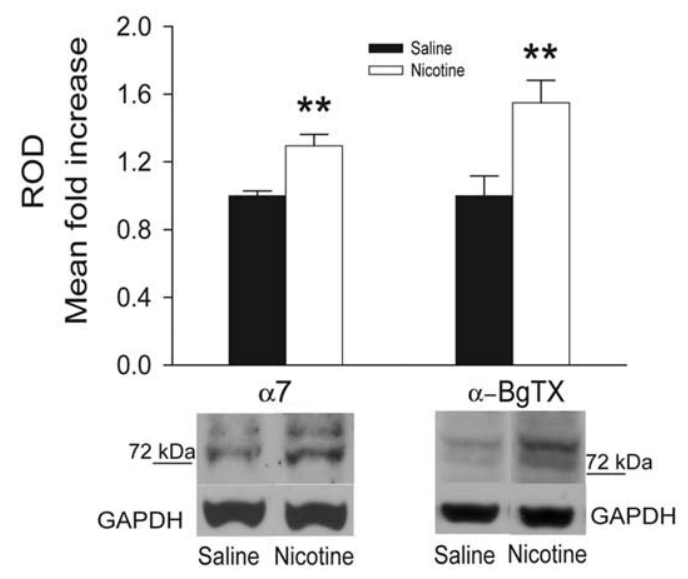

b

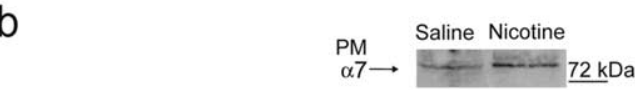

C
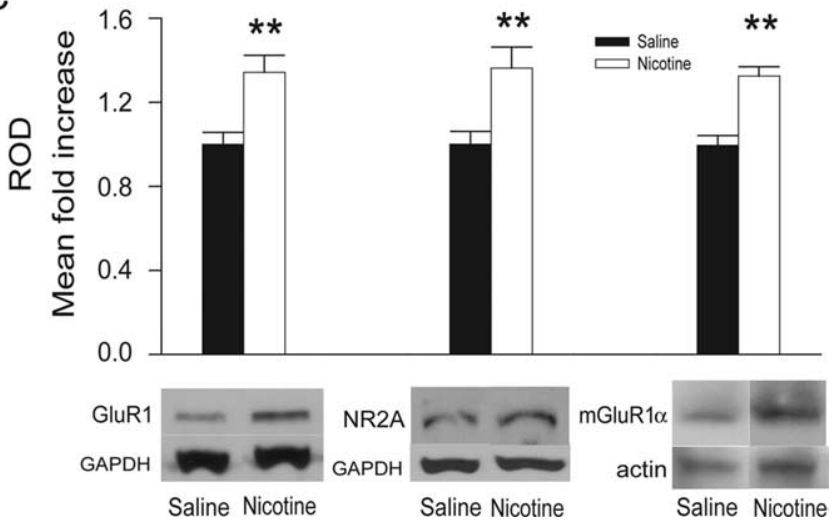

Figure 1. Treatment with $0.5 \mathrm{mg} / \mathrm{kg}$ nicotine increases the levels of presynaptic and postsynaptic proteins. PFC cell lysates from saline- or nicotine-treated mice were subjected to Western blot analysis, followed by densitometric quantification. The experiments were conducted using antibodies against the $\alpha 7 \mathrm{nAChR}$ subunit, the GluR1 AMPA receptor subunit, the NR2A NMDA receptor subunit, and the metabotropic receptor mGluR1 $\alpha . \alpha$-Bungarotoxin binding sites were detected with biotin-conjugated $\alpha$-bungarotoxin/streptavidin-HRP. $\boldsymbol{a}$, Nicotine treatment increased the total levels of $\alpha 7$. The presence of $\alpha 7$ was detected with either a rabbit polyclonal anti- $\alpha 7$ antibody (left, $\alpha 7$ ) or biotin-conjugated $\alpha$-bungarotoxin/streptavidinHRP (right, $\alpha$-BgTX). $\boldsymbol{b}$, Nicotine exposure led to increased levels of $\alpha 7 \mathrm{nAChR}$ at the plasma membrane (PM) as detected with the anti- $\alpha 7$ antibody. $c$, Western blot analysis was also conducted to examine the effects of nicotine on GluR1 (left). Quantification of total GluR1 in cell lysates from saline-treated and nicotine-treated mice indicated that nicotine significantly increased the cellular levels of the AMPA receptor subunit. Similarly to $\alpha 7$ and GluR1, nicotine increased the levels of total NR2A significantly (middle). The same effect was observed when the total levels of $\mathrm{mGluR} 1 \alpha$ were measured (right). ${ }^{* *} p<0.01$. ROD, Relative optical density.

form (lighter band) of $\alpha 7$. The presence of two bands on Western blot (one determined to be the glycosylated form of the receptor) has been reported previously for the $\beta 2 \mathrm{nAChR}$ subunit (Corringer et al., 2006). In addition, we established that this nicotine regimen was sufficient to increase the levels of $\alpha 7$ at the plasma membrane (Fig. 1b) (for similar results obtained in nicotinetreated, differentiated PC12 cells, see supplemental Fig. $1 d$, available at www.jneurosci.org as supplemental material). In this experiment, $\alpha 7$ was detected as a single band with a molecular weight corresponding to the heavier band in Figure $1 a$.

We also found that the total levels of the AMPA receptor subunit GluR1 were increased by $34 \%$ (Fig. 1c, left; six saline- vs six nicotine-treated mice; $p=0.006$ ), and those of the NMDA receptor subunit NR2A were increased by $36 \%$ (Fig. 1c, middle; 10 saline- vs 12 nicotine-treated mice; $p=0.008$ ). Protein levels for the metabotropic glutamate receptor GluR $1 \alpha$ increased by $30 \%$ (Fig. $1 c$, right; four saline- vs five nicotine-treated mice; $p=$ $0.001)$. Because proteasomal inhibition can result in slower protein degradation rates (Malik et al., 2001), we next examined the possibility that the increase in total receptor proteins was attributable to a decrease in proteasomal activity.

\section{Higher levels of ubiquitinated proteins in the presence of nicotine}

Based on the fact that proteasomal inhibition causes the depletion of free ubiquitin and the accumulation of multiubiquitinated proteins (Mimnaugh et al., 1999), we used the p62-derived UBA domain to pull down multi-ubiquitinated proteins from the PFC of mice treated with either saline or 0.5 $\mathrm{mg} / \mathrm{kg}$ nicotine intraperitoneally every $6 \mathrm{~h}$, for $24 \mathrm{~h}$. P62 is a cytoplasmic protein that specifically interacts noncovalently with ubiquitin. Its sequence contains a motif -the ubiquitin associated (UBA) domain- that can, by itself, bind to ubiquitinated proteins (supplemental Fig. 2, available at www.jneurosci.org as supplemental material). Figure $2 a$ shows that an anti-ubiquitin antibody could detect increased total levels of ubiquitinated proteins $2 \mathrm{~h}$ after the last nicotine treatment $(25$ saline- vs 18 nicotine-treated mice; $p=0.006$ ). Quantification of the p62 pull-down blots indicated a $32 \%$ increase in total levels of ubiquitinated proteins (Fig. $2 b$ ). The effects of nicotine persisted for $12 \mathrm{~h}$ after the last injection (Fig. $2 a, b$; three saline- vs three nicotine-treated mice; $p=0.03$ ) but disappeared $18 \mathrm{~h}$ after treatment (Fig. $2 a, b$; three saline- vs three nicotine-treated mice; $p=0.3$ ). The effects of nicotine at 2 versus $12 \mathrm{~h}$ were not significantly different $(p=0.34)$. The time course of the effects of nicotine is compatible with the finding that $\mathrm{nAChR}$ upregulation returns close to baseline after $10 \mathrm{~h}$ (Gentry and Lukas, 2002). Our results resemble those showing that increases in neuronal activity augment the ubiquitination of postsynaptic proteins (Ehlers, 2003; Bingol and Schuman, 2006).

We also examined whether nicotine treatment increased the levels of ubiquitinated $\alpha 7 \mathrm{nAChR}$ subunit using $\mathrm{p} 62$ pull down followed by probing with an anti- $\alpha 7$ antibody. Nicotine significantly increased the intensity of the ladder of ubiquitinated $\alpha 7$ (Fig. 3a). Quantification of the p62 pull-down blots showed a $24 \%$ increase in levels of ubiquitinated $\alpha 7$ (Fig. $3 a$, left; three saline-treated mice vs three nicotine-treated mice; $p=0.02$ ). Similar results were obtained when $\alpha 7$ was detected with biotinconjugated $\alpha$-bungarotoxin (Fig. 3a, right; 33\% increase, seven saline- vs eight nicotine-treated mice; $p=0.02$ ). The data presented here are the first report of the $\alpha 7 \mathrm{nAChR}$ subunit being ubiquitinated. Supplemental Figure $1 a-c$ (available at www. jneurosci.org as supplemental material) provides additional information on $\alpha 7$ regulation by the UPS in control conditions and in the presence of nicotine.

We next examined whether nicotine treatment would similarly lead to accumulation of ubiquitinated glutamate receptors (Fig. 3b). Indeed, p62 pull-down experiments revealed that nicotine significantly increased the levels of ubiquitinated GluR1 AMPA receptor subunit (Fig. $3 b$, left; five saline-treated mice vs five nicotine-treated mice; $p=0.004$ ) and ubiquitinated NR2A NMDA receptor subunit (Fig. $3 b$, middle; three saline-treated mice vs three nicotine-treated mice; $p=0.02$ ). The levels of ubiquitinated GluR1 were increased by $63 \%$, whereas those of NR2A were increased by $70 \%$. We also detected a $40 \%$ increase in the 
a

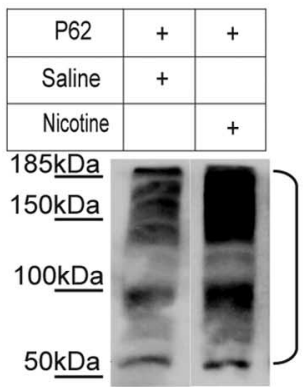

IB: anti-ubiquitin

$2 \mathrm{~h}$

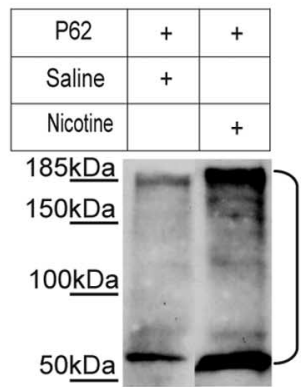

IB: anti-ubiquitin

$12 \mathrm{~h}$

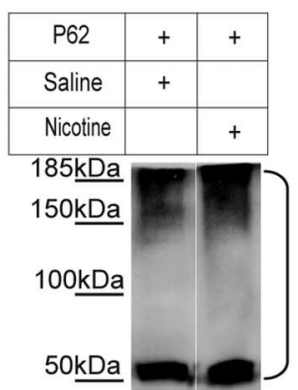

IB: anti-ubiquitin b

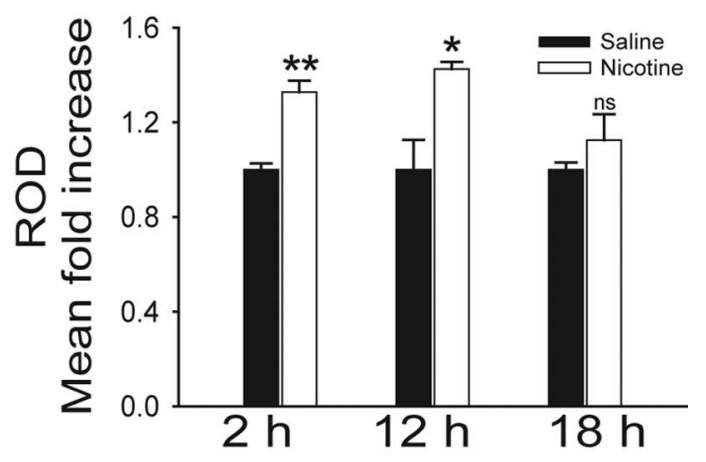

Figure 2. Nicotine increases the total level of ubiquitinated proteins in vivo. Mice were treated with either saline or $0.5 \mathrm{mg} / \mathrm{kg}$ nicotine every $6 \mathrm{~h}$ for $24 \mathrm{~h}$. $\boldsymbol{a}, \mathrm{PFCs}$ were removed 2,12, or $18 \mathrm{~h}$ after the last injection, and lysates were subjected to p62 pull down, followed by Western blot analysis with an anti-ubiquitin antibody. Western analysis of p62 pull-down experiments indicated that nicotine treatment increases accumulation of ubiquitinated proteins in the PFC. The brackets on the right mark a ladder of bands corresponding to polyubiquitinated proteins. $\boldsymbol{b}$, Quantification of the results indicated that the effects of nicotine persist $12 \mathrm{~h}$ after injection. ${ }^{*} p<0.05$; ${ }^{* *} p<0.01$. IB, Immunoblot; ROD, relative optical density.

amount of ubiquitinated mGluR1 $\alpha$ (Fig. 3b, right; four salinetreated mice vs six nicotine-treated mice), but this increase failed to reach statistical significance $(p=0.2)$. However, when differentiated PC12 cells, which express mGluR $1 \alpha$ receptors, were exposed to nicotine, there was a clear increase in ubiquitinated mGluR $1 \alpha$ on pull down with p62. In the same experiments, nicotine reduced the degradation of the $\mathrm{mGluR} 1 \alpha$ receptor protein (for an example of the two independent experiments we conducted, see supplemental Fig. 3, available at www.jneurosci.org as supplemental material).

\section{Nicotine decreases the degradation of PSD-95 but increases that of Shank}

At the synapse, glutamate receptors associate with several other proteins involved in scaffolding and signal transduction (Kim and Sheng, 2004). To investigate whether nicotine exposure affects the degradation of proteins that are fundamental for the architecture of the synapse, we used p62 to pull down the ubiquitinated forms of the scaffolding proteins PSD-95 and Shank. Both PSD-95 and Shank can be ubiquitinated (Colledge et al., 2003; Ehlers, 2003). Immunoblots showed a significant increase (12\%) of ubiquitinated PSD-95 with nicotine treatment (Fig. 4a, left; 14 saline-treated mice vs 12 nicotine-treated mice; $p=0.04)$. The total levels of PSD-95 protein were increased by $11 \%$ (Fig. $4 a$, right; 17 saline-treated mice vs 15 nicotine-treated mice; $p=$ $0.01)$. Interestingly, the ladder of ubiquitinated Shank was less pronounced in nicotine-treated mice. Quantification of the p62 pull-down blots showed $60 \%$ decrease in ubiquitinated Shank (Fig. $4 b$, left; four saline-treated mice vs four nicotine-treated mice; $p=0.002$ ), and total levels of Shank protein were reduced by $16 \%$ (Fig. $4 b$, right; seven saline-treated mice vs nine nicotinetreated mice; $p=0.009$ ).

\section{Nicotine inhibits proteasomal activity in vivo}

The $26 \mathrm{~S}$ proteasome is a large intracellular protease comprising a polar 19S cap in which proteins are recognized and unfolded, and a central 20S barrel-shaped structure that contains an inner proteolytic chamber (Hegde and DiAntonio, 2002). To determine whether nicotine inhibits proteasomal activity in vivo, male C57BL/6J mice were injected intraperitoneally with either 0.5 $\mathrm{mg} / \mathrm{kg}$ nicotine or saline. Equal protein aliquots of tissue extracts from the PFC were fractionated by glycerol density-gradient cen- trifugation in either absence or presence of ATP. The average proteasomal chymotrypsin-like activity was calculated from proteasome-enriched fractions.

In the absence of ATP (Fig. $5 a$, left), the treatment with 0.5 $\mathrm{mg} / \mathrm{kg}$ nicotine led to $21 \%$ inhibition ( $n=10$ for both experimental groups; $p=0.0002$ ). Proteasomal activity was also measured in the presence of ATP, which better preserves the structure of the $26 \mathrm{~S}$ complex (Fig. $5 a$, right). In these experimental conditions, treatment with $0.5 \mathrm{mg} / \mathrm{kg}$ led to a $15 \%$ inhibition (six saline- vs five nicotine-treated mice; $p=0.022$ ). Similar levels of proteasomal inhibition by nicotine were also observed in PC12 cells (supplemental Fig. 1e, available at www.jneurosci.org as supplemental material). To test whether the inhibition by nicotine of proteasomal activity was attributable to a decrease in the expression levels of its constituents, we measured the total levels of the $20 \mathrm{~S}$ proteasome and the $19 \mathrm{~S}$ regulatory complex in unfractionated PFC lysates. We found that nicotine did not decrease but, in fact, significantly increased the levels of the 20S core by $37 \%$ (Fig. $5 b$, left; $p=0.046$ ) and those of the 19 S regulatory cap by $26 \%$ (Fig. $5 b$, right; $p=0.008$ ). After glycerol gradient fractionation, samples were probed with antibodies against the $20 \mathrm{~S}$ core subunits (Fig. 5c) and the Rpt6/S8 ATPase subunit of the 19S regulator of the $26 \mathrm{~S}$ proteasome (Fig. $5 d$ ). In both cases, nicotine treatment increased the levels of detected proteins.

Our data indicate that expression levels of various $26 \mathrm{~S}$ components are not reduced after nicotine treatment and suggest that the nicotine-induced decrease in proteasomal catalytic activity is attributable to the interaction of the drug with the proteasome rather than decreases in the expression levels of catalytic subunits and regulatory ATPases. In fact, the expression levels of select subunits were shown to increase in PFC lysates after nicotine treatment, which may represent a homeostatic cellular response to decreased proteasomal activity (Kane et al., 2004).

\section{nAChR-independent mechanisms may contribute to the inhibition of proteasomal activity by nicotine}

To examine whether the presence of nAChRs is necessary for the inhibition by nicotine of proteasomal activity, $0.5 \mathrm{mg} / \mathrm{kg}$ nicotine was injected in mice $30 \mathrm{~min}$ after the injection of $2 \mathrm{mg} / \mathrm{kg}$ mecamylamine, a nonselective $\mathrm{nAChR}$ antagonist that at the doses used can block the behavioral effects of nicotine (Collins et al., 1986; David et al., 1994). Mecamylamine partially inhibited 
a

\begin{tabular}{|c|c|c|}
\hline P62 & + & + \\
\hline Saline & + & \\
\hline Nicotine & & + \\
\hline $17 \underline{\mathrm{kDa}}$ & & + \\
$13 \underline{\mathrm{kDa}}$ & & \\
$\underline{95 \mathrm{kDa}}$ & & \\
$\underline{72 \mathrm{kDa}}$ & \\
\hline
\end{tabular}

IB: $\alpha 7$

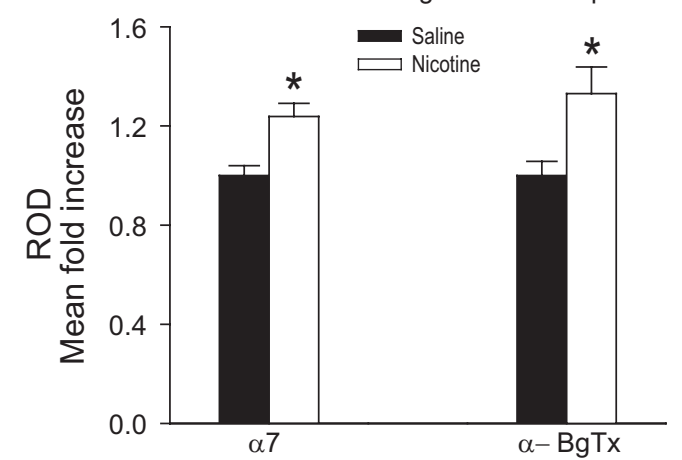

b

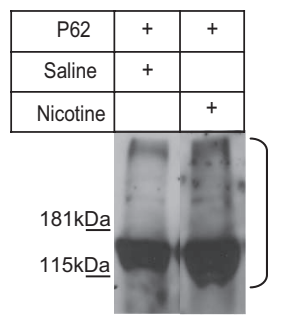

IB: GLUR1

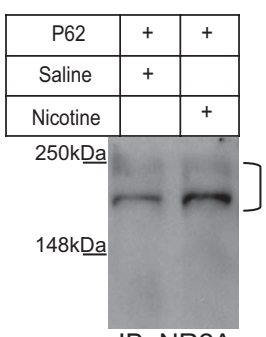

IB: NR2A

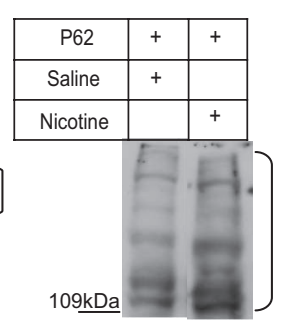

IB: $m G L U R 1 \alpha$

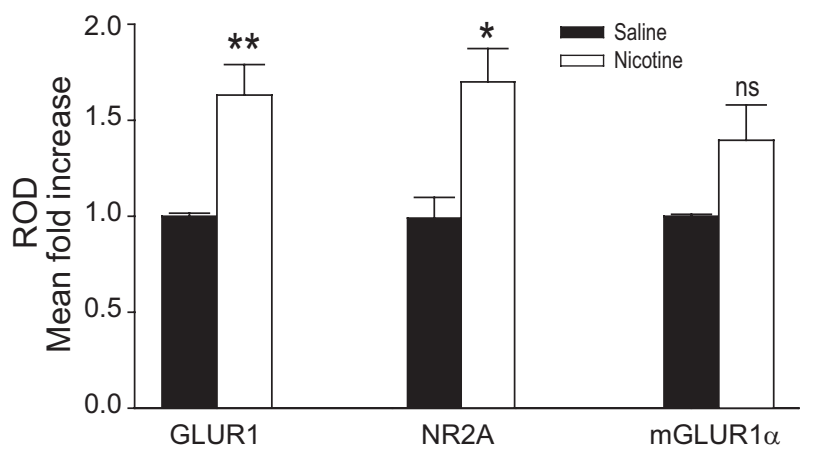

Figure 3. In vivo accumulation of ubiquitinated receptors in the presence of nicotine. PFC cell lysates from saline- or nicotine-treated mice were subjected to p62 pull down, followed by probing with antibodies against the $\alpha 7 \mathrm{nAChR}$ subunit or various glutamate receptor subunits. In addition, $\alpha 7$ was detected using biotin-conjugated $\alpha$-bungarotoxin/streptavidin-HRP. $\boldsymbol{a}$, Nicotine treatment increased the ubiquitinated levels of $\alpha 7$. Similar results were obtained when $\alpha 7$ was detected with an anti- $\alpha 7$ antibody (top left) or biotin-conjugated $\alpha$-bungarotoxin (top right). The bottom diagram reports the quantification of the experiments with anti- $\alpha 7$ (bottom left) and $\alpha$-bungarotoxin (bottom right), respectively. $\boldsymbol{b}$, Nicotine treatment increased significantly the ubiquitinated levels of the AMPA receptor subunit GluR1 (top and bottom left) and the NMDA receptor subunit NR2A (top and bottom middle). In the presence of nicotine, there was also a trend increase in the ubiquitinated levels of the metabotropic receptor $m G l u R 1 \alpha$, but the increase observed was not statistically significant (top and bottom right). The brackets on the right mark a ladder of bands corresponding to polyubiquitinated proteins. ${ }^{*} p<0.05$; ${ }^{* *} p<0.01$. IB, Immunoblot; $\alpha 7, \alpha 7 \mathrm{nAChR}$ subunit; $\alpha$-BgTx, $\alpha$-bungarotoxin; $R O D$, relative optical density. the effect of nicotine on total levels of ubiquitinated proteins (Fig. $6 a ; 18$ saline-treated mice vs 18 nicotine-treated mice vs 10 mecamylamine plus nicotine-treated mice; $p=0.0001$ saline vs nicotine; $p=0.03$ saline vs mecamylamine plus nicotine; $p=$ 0.0018 nicotine vs mecamylamine plus nicotine). In the presence of mecamylamine, nicotine produced a $13 \%$ increase in total ubiquitinated proteins compared with a $33 \%$ increase attained by nicotine treatment alone. Mecamylamine also partially prevented the inhibitory effect of nicotine on chymotrypsin-like activity. In this set of experiments, nicotine alone yielded a $25 \%$ inhibition of chymotrypsin-like activity, whereas it produced a $14 \%$ block in animals pretreated with mecamylamine (Fig. $6 b$; 13 saline-treated mice vs 14 nicotinetreated mice vs 14 mecamylamine plus nicotine- treated mice; $p=0.0008$ saline vs nicotine; $p=0.02$ saline vs mecamylamine plus nicotine; $p=0.12$ nicotine vs mecamylamine plus nicotine). To further assess whether the influence of nicotine on proteasomal activity occurs through nAChR-mediated mechanisms, we conducted experiments on HEK-293 cells, which do not express nAChRs. Even in the absence of nAChRs, treatment of HEK-293 cells with $500 \mathrm{~nm}$ nicotine increased total levels of ubiquitinated proteins significantly (Fig. $6 c ; 17 \%$ increase; nicotine vs control, $n=3 ; p=0.005)$. The same dose of nicotine inhibited the activity of the proteasome by $17 \%$ (Fig. $6 d$; nicotine vs control, $n=7 ; p=0.002$ ).

To determine whether the presence of nAChRs is necessary for nicotine to affect the proteasomal degradation of non-nAChR proteins, we transiently transfected HEK-293 cells with Tygtagged Homer-1A. Homer-1A was chosen because it is a shortlived adaptor protein involved in the stability and signaling cascade of mGluR1 $\alpha$ (Ciruela et al., 1999; Ehrengruber et al., 2004). In addition, Homer-1A has been used previously to evaluate the effects of putative proteasome inhibitors on protein turnover (Dantuma et al., 2000; Ageta et al., 2001). HEK-293 cells expressing Homer-1A were exposed for $24 \mathrm{~h}$ to the protein synthesis blocker emetine in the presence of either the proteasome inhibitor MG132 or $500 \mathrm{~nm}$ nicotine (Fig. 6e,f). Cell lysates were subjected to Western blot analyses, and the presence of Homer-1A was detected with an anti-Tyg monoclonal antibody. Nicotine significantly reduced the proteasomal degradation of Homer-1A (Fig. 6e), independently of the expression of nAChRs. Exposure to $500 \mathrm{nM}$ nicotine resulted in a $160 \%$ increase in total levels of Homer-1A (Fig. $6 e ; 500 \mathrm{~nm}$ nicotine vs control; $p=0.04 ; n=10$ for both groups). Nicotine treatment also resulted in an increase in ubiquitinated Homer-1A (Fig. $6 f$ ), confirming that the degradation of the protein by the UPS was reduced in the presence of nicotine.

Overall, our data suggest that the effect of nicotine on the proteasome are, at least partially, independent of nAChR expression. This observation might point to the mechanisms underlying the effect of nicotine on non-neuronal tissues.

\section{Nicotine inhibits the activity of purified proteasomes}

To investigate whether nicotine affects the proteasome directly, we assessed its effects on the activity of $20 \mathrm{~S}$ proteasomes purified from human erythrocytes. The $20 \mathrm{~S}$ proteasome, the substrate peptide, and nicotine (300 and $500 \mathrm{~nm}$ ) or MG132 (1 nM to 10 $\mu \mathrm{M})$ were incubated for $1 \mathrm{~h}$ in assay buffer. In this system, nicotine inhibited chymotrypsin-like proteasomal activity by $15 \%$ at both concentrations tested (Fig. $7 a ; 300 \mathrm{nM}, n=8,500 \mathrm{nM}, n=3$; $p<0.00001$ control vs both nicotine concentrations). The effects of nicotine were comparable with those of MG132 at concentrations between 1 and $10 \mathrm{~nm}$ (Fig. 7b). 

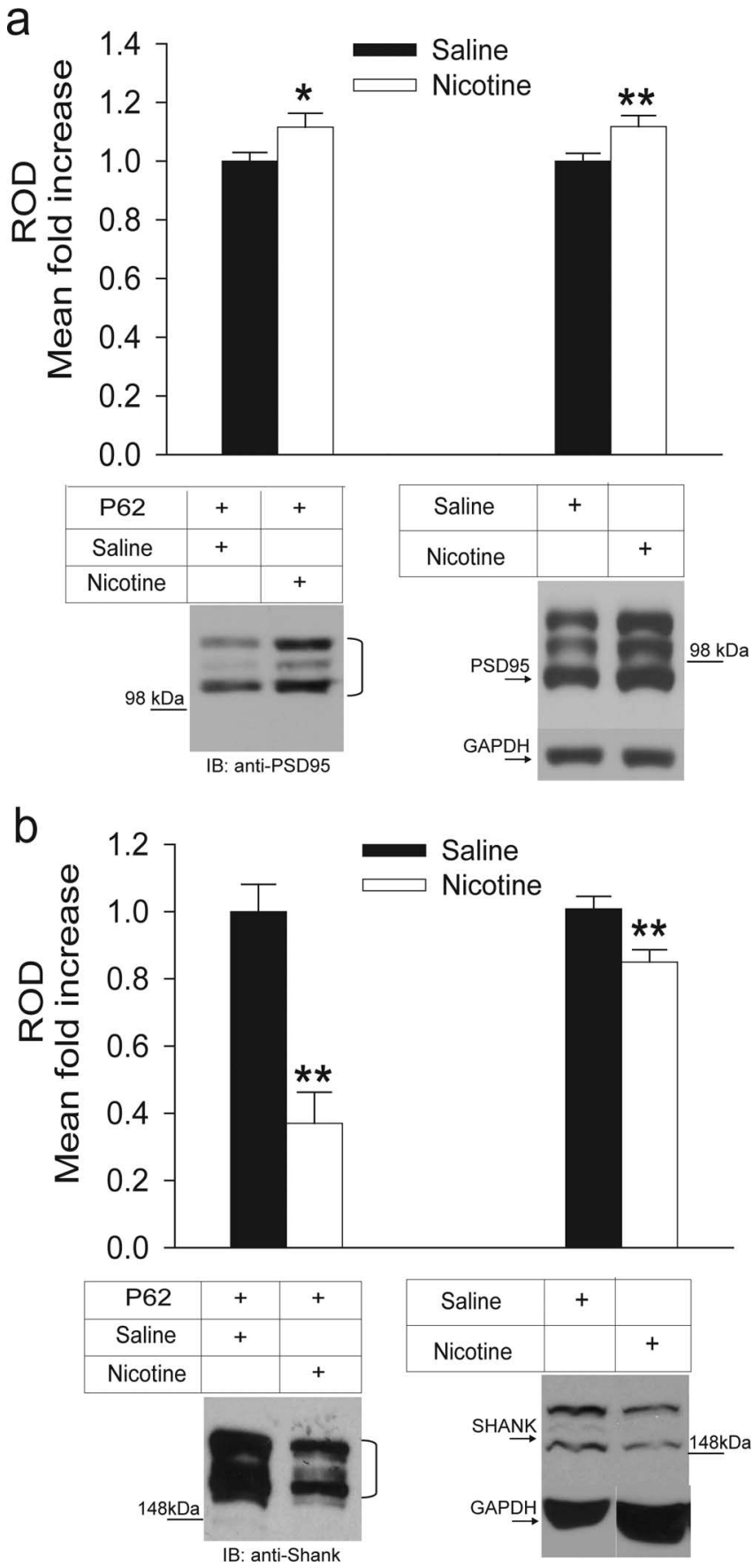

Figure 4. The effects of nicotine on the scaffolding proteins PSD-95 and Shank. PFC cell lysates from saline- or nicotine-treated mice were subjected to $\mathrm{p} 62$ pull down, followed by Western blotting with anti-PSD-95 or pan anti-Shank. $\boldsymbol{a}$, Nicotine treatment increased the levels of ubiquitinated PSD-95 significantly (top and bottom left). We also probed total tissue lysates with anti-PSD-95 antibody and found that nicotine increased the total levels of PSD-95 protein significantly (top and bottom right). $\boldsymbol{b}$, Anti-Shank antibodies were used to analyze p62 pull-down experiments and revealed that the levels of ubiquitinated Shank were decreased significantly (top and bottom left). Total tissue lysates were also probed with anti-Shank antibodies. Results showed that nicotine significantly decreased the total levels of Shank protein (top and bottom right). The brackets on the right in $\boldsymbol{a}$ and $\boldsymbol{b}$ mark a ladder of bands corresponding to polyubiquitinated PSD-95 and Shank proteins, respectively. ${ }^{*} p<0.05$; ${ }^{* *} p<0.01$. IB, Immunoblot; ROD, relative optical density.

Experiments were also conducted to detect the effects of nicotine on the $26 \mathrm{~S}$ form of proteasomes purified from human erythrocytes (Fig. 7c). In these experimental conditions, 300 and a

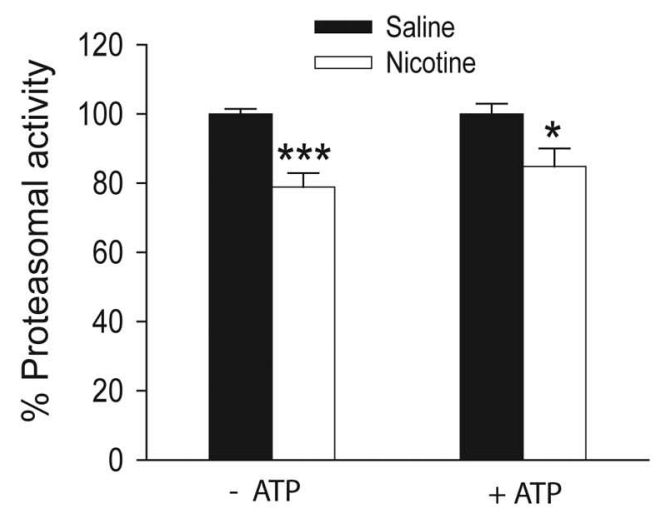

b
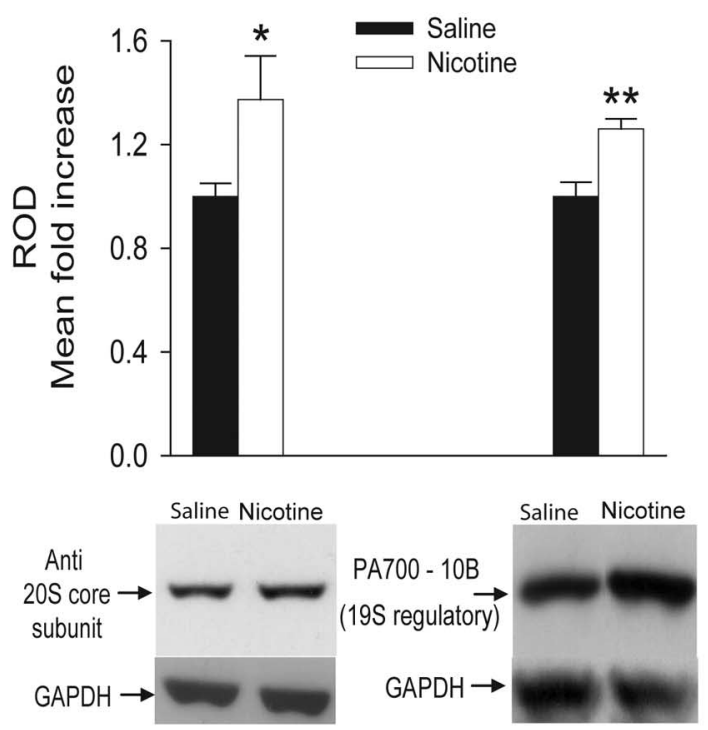

C
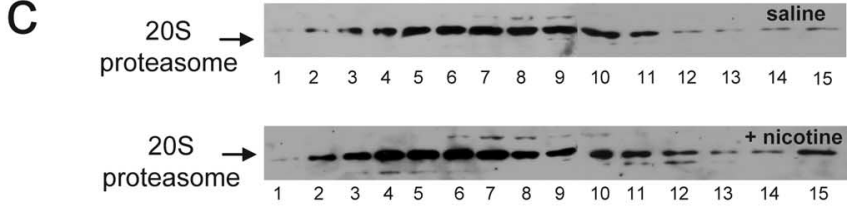

d
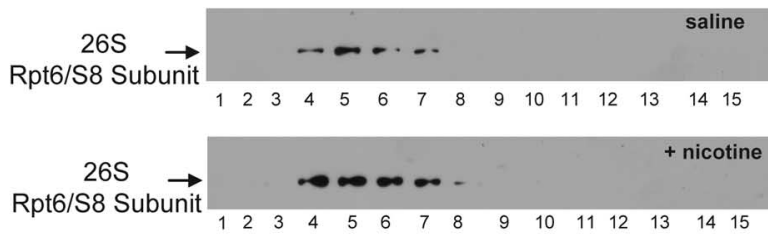

Figure 5. Decreased proteasomal activity in the PFC of (57BL/6J mice treated with nicotine. The PFC of mice treated with saline or $0.5 \mathrm{mg} / \mathrm{kg}$ nicotine was homogenized in either the absence or presence of ATP. $\boldsymbol{a}, \mathrm{In}$ the absence of ATP (left), treatment with nicotine decreased proteasomal chymotrypsin-like activity by $21 \%$. A similar decrease (15\%) was observed when proteasomal chymotrypsin-like activity was measured in the presence of ATP (right). $\boldsymbol{b}$, Total levels of 205 core and 195 regulatory subunits were examined and quantified in unfractionated PFC lysates from mice injected with saline or $0.5 \mathrm{mg} / \mathrm{kg}$ nicotine in the presence of ATP. Equal amounts of protein were loaded onto a 12\% SDS gel and probed with anti-20S proteasome core subunits (left) or anti-proteasome activator PA700 subunit 10b (right). Quantification of the Western blots showed statistically significant increases in the total levels of 205 proteasome core subunits and the total level of 195 regulatory complex with nicotine treatment. $\boldsymbol{c}, \boldsymbol{d}$, After glycerol gradient fractionation, collected PFC fractions (35 $\mu$ l) were loaded onto a 12\% SDS gel and probed with antibodies that recognize the 20S proteasome core subunits or the Rpt6/S8 ATPase of the 195 regulatory complex. Nicotine treatment increased the levels of the two subunits tested. The numbers under each blot represent the corresponding collected fraction (for additional detail, see Materials and Methods). ${ }^{*} p<0.05$; ${ }^{* *} p<0.01$; ${ }^{* * *} p<0.001$. ROD, relative optical density. 
a
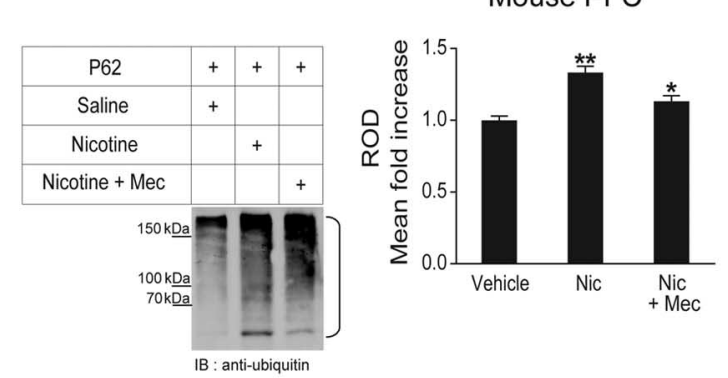

HEK 293 cells

C
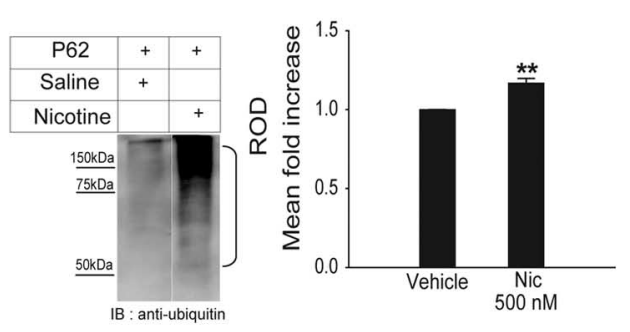

e
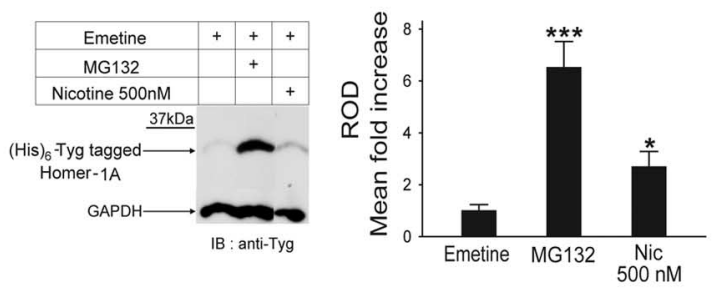

$\mathrm{b}$
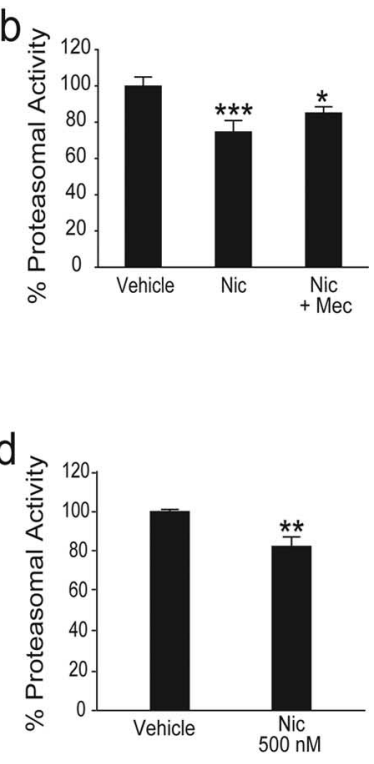

f

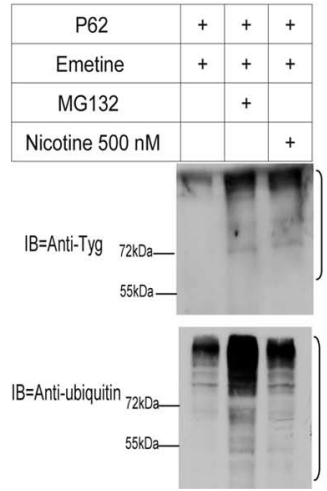

Figure 6. nAChR activation only partially mediates the effects of nicotine on proteasomal catalytic activity. $\boldsymbol{a}, \boldsymbol{b}$, The PFC of mice treated with saline, $0.5 \mathrm{mg} / \mathrm{kg}$ nicotine, or $2 \mathrm{mg} / \mathrm{kg}$ mecamylamine followed by $0.5 \mathrm{mg} / \mathrm{kg}$ nicotine was homogenized and subjected to p62 pull down $(\boldsymbol{a})$ or assayed for chymotrypsin-like activity $(\boldsymbol{b})$. Mecamylamine could only partially block the inhibitory effects of nicotine on the proteasome. $\boldsymbol{c}, \boldsymbol{d}$, Lysates of HEK-293 cells treated with nicotine ( $500 \mathrm{~nm}$ ) or vehicle were subjected to $\mathrm{p} 62$ pull down (c) or assayed for chymotrypsin-like proteasomal activity (d). Nicotine at $500 \mathrm{~nm}$ produced significant accumulation of ubiquitinated proteins (c) and inhibited proteasomal activity $(\boldsymbol{d})$ in this cell line, which does not express nAChRs. $\boldsymbol{e}, \boldsymbol{f}$, In separate experiments, HEK-293 cells transfected with (His) ${ }_{6}$-Tyg tagged Homer-1A were treated with emetine along with MG132, a known proteasomal inhibitor, or $500 \mathrm{~nm}$ nicotine. Equal amounts of protein from cell lysates were either loaded onto a $12 \%$ SDS gel (e) or were subjected to p62 pull down $(\boldsymbol{f})$, followed by Western blot analysis with an anti-Tyg $(\boldsymbol{e}, \boldsymbol{f}$, top) or an anti-ubiquitin antibody $(\boldsymbol{f}$, bottom). Nicotine increased the stability of Homer-1A significantly $(\boldsymbol{e})$. The levels of ubiquitinated Homer-1A were also increased in the presence of nicotine compared with control $(\boldsymbol{f})$. The p62 experiments were repeated once with the same result. MG132 was used as a positive control. The brackets on the right of $\boldsymbol{a}, \boldsymbol{c}$, and $\boldsymbol{f}$ mark a ladder of bands corresponding to the polyubiquitinated proteins. ${ }^{*} p<0.05 ;{ }^{* *} p<0.01 ;{ }^{* * *} p<0.001$. Mec, Mecamylamine; Nic, nicotine; IB, immunoblot; ROD, relative optical density.

$500 \mathrm{~nm}$ nicotine inhibited 26S chymotrypsin-like activity by 12 and $20 \%$, respectively $(n=6$ for all experimental conditions; 300 nM nicotine vs control, $p=0.01 ; 500$ nM nicotine vs control, $p=$ $0.0002)$.

To investigate the possible mechanisms of the nicotine/proteasome interaction, we conducted homologous radioligand binding experiments incubating $1 \mu \mathrm{M}\left[{ }^{3} \mathrm{H}\right]$-nicotine (with or without cold nicotine) with partially purified proteasomes from HEK-293 cells (Kisselev and Goldberg, 2005). Our data show that radiolabeled nicotine directly and specifically binds to the proteasome $\left(0.52 \pm 0.08 \mathrm{fmol}\left[{ }^{3} \mathrm{H}\right]\right.$ nicotine $/ \mathrm{mg}$ proteasome vs $0.13 \pm 0.003 \mathrm{fmol}\left[{ }^{3} \mathrm{H}\right]$ nicotine $/ \mathrm{mg}$ proteasome in the presence of cold nicotine; $n=3 ; p=0.008$ ). Overall, these results point to the ability of nicotine to directly interact with the proteasome

complex and suggest a possible mechanism for its inhibitory effects.

\section{Discussion}

We show that nicotine, at concentrations found in the plasma of smokers, acts as a partial proteasomal inhibitor in a manner that is partly nAChR independent. Proteasomal inhibition by nicotine leads to the accumulation of ubiquitinated proteins in the cell. Because protein degradation by the UPS results from a balance between the activity of ubiquitinating and deubiquitinating enzymes, ubiquitinated proteins that cannot be degraded will be eventually "recycled" via deubiquitination and spared from degradation (Mimnaugh et al., 1999; Wu et al., 2004). This is the most plausible explanation for our results because nicotine-induced increases in ubiquitinated proteins result from proteasomal inhibition. If nicotine increased protein ubiquitination without blocking the proteasome (for example by inhibiting deubiquitinating enzymes), we would expect faster rates of protein degradation, which would be reflected by lower, rather than higher, levels of proteins in cell lysates. Conversely, if nicotine decreased protein ubiquitination, the intensity of the ladder corresponding to ubiquitinated proteins would be reduced, whereas the total level of proteins would be increased.

We focused on how the nicotine/proteasome interaction affects the cellular levels of nicotinic and glutamate receptors and two scaffolding proteins, PSD-95 and Shank. The interaction with the UPS appears to affect $n A C h R$ upregulation and produce changes in glutamatergic receptor levels that are similar to those observed during LTP.

\section{The UPS and nicotine-induced nAChR upregulation}

Nicotine is the main addictive component of tobacco (Dani and Harris, 2005). Exposure to nicotine increases the number of nAChRs at the plasma membrane, and this phenomenon is believed to contribute to the drug-induced plasticity that underlies nicotine addiction (Buisson and Bertrand, 2002). Mechanisms proposed for $\mathrm{nAChR}$ upregulation include receptor desensitization, decreased receptor degradation, and increased ER maturation of subunits that would otherwise be degraded (Peng et al., 1997; Wang et al., 1998; Fenster et al., 1999a; Sallette et al., 2005). Our results suggest that nicotine influences $\mathrm{nAChR}$ maturation and degradation by interacting with the UPS. We first showed that the $\alpha 7$ subunit is a target of the UPS and then demonstrated that inhibition of proteasomal catalytic activity by nicotine causes accumulation of ubiquitinated $\alpha 7$. Our results can be explained based on the known role of the UPS at the ER level as part of the 

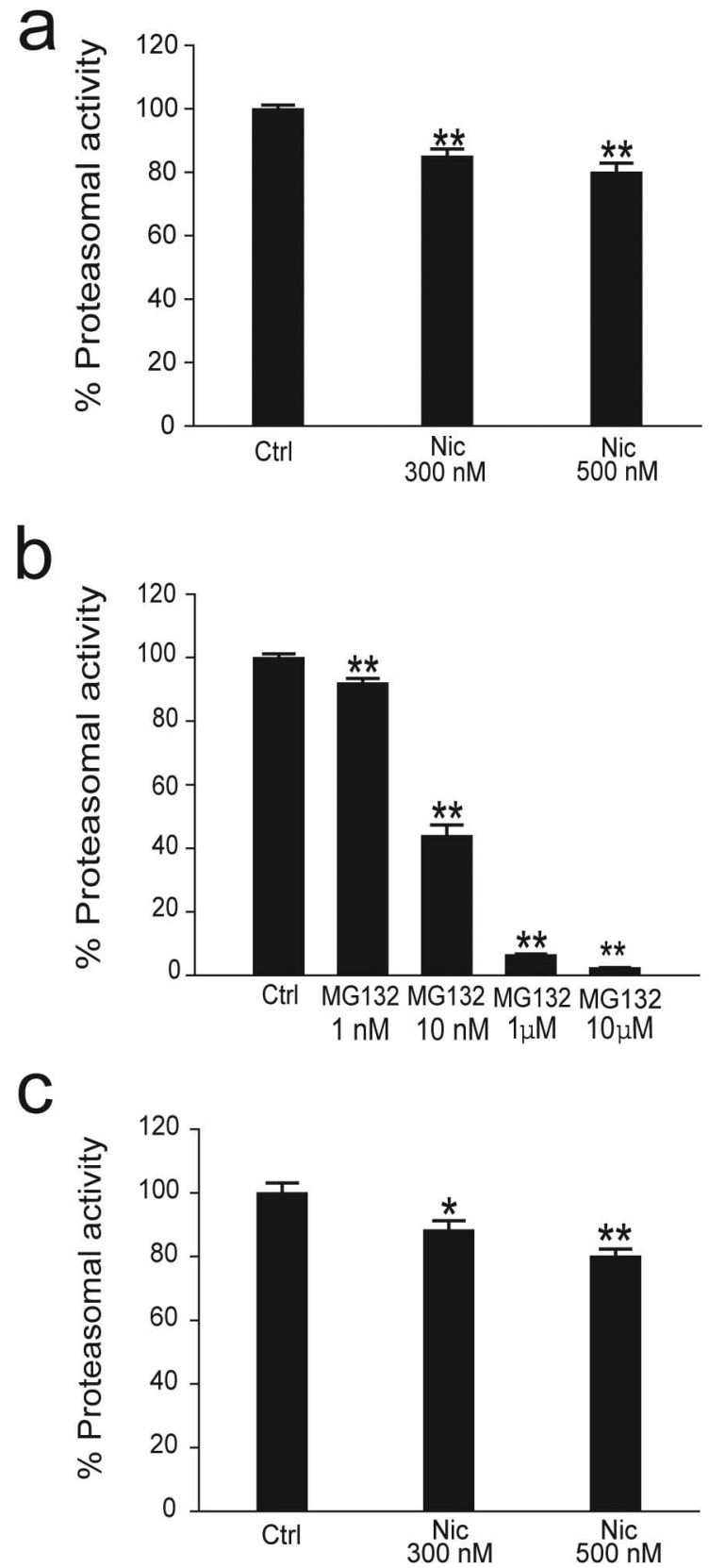

Figure 7. Nicotine inhibits the chymotrypsin-like activity of purified 205 and 265 human proteasomes. $\boldsymbol{a}$, The chymotrypsin-like activity of $20 \mathrm{~S}$ proteasomes purified from human erythrocytes was assessed in vitro in the presence of vehicle, $300 \mathrm{~nm}$ nicotine, or $500 \mathrm{~nm}$ nicotine. Nicotine inhibited proteasomal activity by 15.0 and $19.1 \%$ at $300 \mathrm{~nm}(n=8)$ and $500 \mathrm{~nm}(n=$ 3), respectively. The inhibition by nicotine was statistically significant at both concentrations tested. $\boldsymbol{b}$, To compare the effects of nicotine with those of a known proteasome inhibitor, the same proteasomal activity assay was performed in the presence of MG 132 concentrations ranging from $1 \mathrm{~nm}$ to $10 \mu \mathrm{M}$. MG132 inhibited proteasomal activity by $7.41,55.5,93.5$, and $94.6 \%$ at $1 \mathrm{~nm}(n=6), 10 \mathrm{~nm}(n=3), 1 \mu \mathrm{M}(n=3)$, and $10 \mu \mathrm{M}(n=13)$, respectively. The inhibitory effects of MG132 were statistically significant at all concentrations tested ( $p<0.0005)$. c, The chymotrypsin-like activity of 265 proteasomes purified from human erythrocytes was assessed in vitro in the presence of vehicle, $300 \mathrm{~nm}$ nicotine, or $500 \mathrm{~nm}$ nicotine. Nicotine inhibited proteasomal activity by 11.65 and $19.87 \%$ at $300 \mathrm{~nm}(n=6)$ and $500 \mathrm{~nm}(n=6)$, respectively. The inhibition by nicotine was statistically significant at both concentrations tested. ${ }^{*} p<0.01$; ${ }^{* *} p<0.001$. Ctrl, Control; Nic, nicotine.

endoplasmic reticulum-associated degradation (ERAD) system. Besides preventing mutant/misfolded proteins from accumulating in the cell, ERAD may regulate the surface density of proteins by controlling the fraction of proteins that mature to multimers (Christianson and Green, 2004; Yan et al., 2005). Hence, partial inhibition of proteasomal ERAD activity by nicotine would give time for $\mathrm{nAChR}$ subunits to undergo the oligomerization necessary to produce mature pentamers (Christianson and Green, 2004; Kuryatov et al., 2005). This hypothesis is supported by data showing that trafficking from the ER is required for nicotineinduced nAChR upregulation in HEK-293 cells (Darsow et al., 2005). Overall, our data suggest that an increase in surface nAChRs may be produced by a more efficient trafficking of mature receptors from the ER/Golgi to the plasma membrane. Whether the effects of nicotine on the proteasome influence the endocytosis of plasma membrane nAChRs remains to be determined (Fig. 8).

\section{The effect of nicotine on the glutamatergic system}

Nicotine can improve cognitive function (Levin, 2002; Newhouse et al., 2004) and facilitate the induction of LTP (Sawada et al., 1994; Ji et al., 2001; Welsby et al., 2006). An increase in postsynaptic responsiveness is one of the ways synaptic efficacy can be enhanced (Malenka and Nicoll, 1999). Key events for this phenomenon are an increased AMPA receptor conductance after GluR1 phosphorylation and an increased number of AMPA receptors at the postsynaptic membrane (Malinow and Malenka, 2002). AMPA receptor trafficking is regulated by the UPS (Burbea et al., 2002), and we show that nicotine exposure produces an accumulation of ubiquitinated GluR1 and increases total GluR1 protein levels. Hence, the effects of nicotine on the proteasome could help promote LTP by increasing the pool of GluR1 subunits available for insertion into the plasma membrane.

Besides a direct effect on GluR1 levels, AMPA receptor trafficking could be promoted by changes in the levels of scaffolding proteins. The interaction of PSD-95 with stargazin controls the synaptic density of AMPA receptors (Chen et al., 2000). PSD-95 ubiquitination leads to its degradation and promotes AMPA receptor internalization, an effect that can be blocked by the proteasome inhibitor MG132 (Patrick et al., 2003). Therefore, the accumulation of PSD-95 after nicotine treatment could also increase AMPA receptor availability. Other investigators have shown that nicotine increases retention of GluR1 receptors in the postsynaptic density (Powers et al., 2005), and our results could provide an explanation for their data.

Activation of NMDA receptors that contain the NR2A subunit promotes LTP (Liu et al., 2004), and LTP induction increases protein levels of NR2A (Grosshans et al., 2002). An increase in NR2A-containing receptor availability might be achieved via both direct and indirect mechanisms. Nicotine may reduce NMDA receptor degradation directly, as suggested by the accumulation of ubiquitinated NR2A and the increase in NR2A protein levels. Others have reported that nicotine increases NR2A levels (Delibas et al., 2005; Wang et al., 2007) possibly without increasing NR2A mRNA levels (Dr. Robert F. Smith, personal communication). The increased levels of PSD-95 could also help to increase NR2A-containing receptor levels during LTP, because PSD-95 tethers NMDA receptors to the cytoskeleton (Kim and Sheng, 2004), and overexpression of PSD-95 promotes synaptic insertion of NR2A (Losi et al., 2003).

mGluR1 $\alpha$ receptors might also be necessary for LTP expression, at least in certain areas of the brain (Conquet et al., 1994; Lynch, 2004). nAChR-mediated enhancement of LTP involves activation of group 1 metabotropic glutamate receptors (Welsby et al., 2006), and the ability of nicotine to slow $\mathrm{mGluR} 1 \alpha$ receptor 


\section{Plasma Membrane}

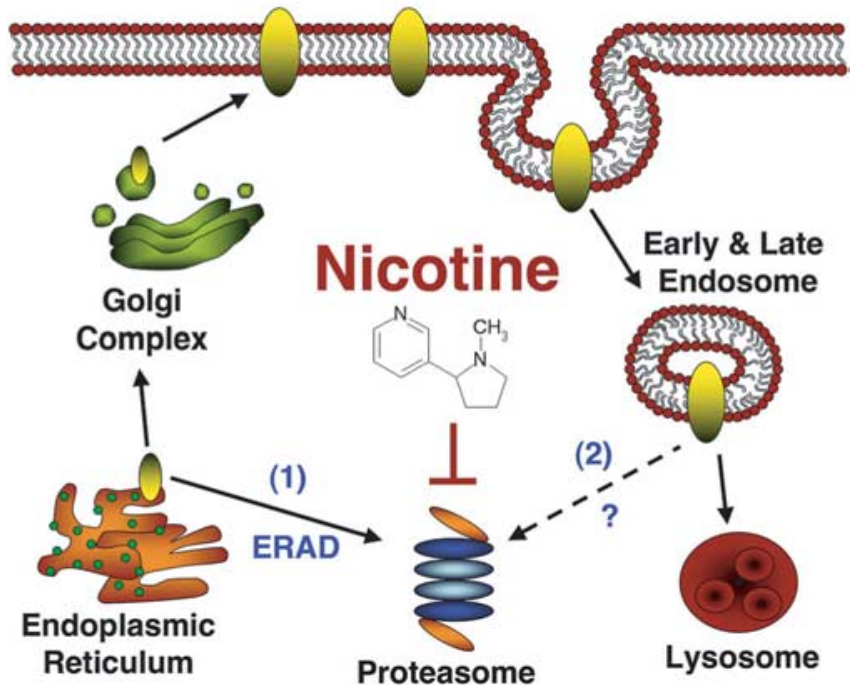

Figure 8. Nicotine regulates protein turnover at the synapse by partially inhibiting the UPS. Schematic representation of the effects of nicotine on the trafficking and degradation of plasma membrane proteins. After synthesis and maturation within the ER, properly folded proteins are allowed to pass the ERAD checkpoint and traffic forward into the secretory pathway through the Golgi apparatus. Our experiments suggest that nicotine, after crossing the cell membrane, acts as a weak proteasomal inhibitor at the ERAD level. The partial inhibition of the proteasome enables proteins to leave the ER more efficiently (1). An additional place for the inhibitory role of nicotine on the proteasome might be the targeting of plasma membrane proteins for proteasomal degradation (2). We propose that nicotine, by interacting with the proteasome, can promote protein maturation. The effect of nicotine on protein turnover remains to be validated.

degradation could contribute to the effects of smoking on mGluR function.

The effect of nicotine seems to be specific for certain proteins/ pathways because we found that nicotine treatment decreased the levels of Shank, the "master scaffold" at the postsynaptic density. The same reduction in Shank protein levels was reported in an in vitro paradigm for increased cortical activity (Ehlers, 2003). The role of the selective changes in scaffolding proteins we observed remains unexplained, but it points to the ability of nicotine to promote the complex changes in localization and turnover of neurotransmitter receptors that modulate neuronal synaptic transmission.

\section{Mechanisms of the nicotine/UPS interaction}

The reduction in proteasomal activity by nicotine treatment is attributable to decreases in catalytic activity rather than reduced expression levels of proteasomal constituents. Others have shown that nicotine exposure increases mRNA levels for some UPS components (Kane et al., 2004), and we detected increased protein levels of proteasomal components with nicotine treatment. This upregulation of genes encoding UPS components might represent a feedback mechanism attempting to counteract proteasomal inhibition.

One important question is how nicotine affects the proteasome. Nicotine may influence the proteasome via both receptor-mediated and receptor-independent mechanisms. Preinjecting mice with mecamylamine partially prevented the effects of nicotine on accumulation of ubiquitinated proteins and chymotrypsin-like activity. The receptor-mediated effect could result from $\mathrm{nAChR}$ coupling to intracellular signal transduction mechanisms. For example, nAChR stimulation may lead to mitogen-activated protein kinase activation
(Dajas-Bailador and Wonnacott, 2004), followed by inhibition of the UPS (Yamashita et al., 2005). Evidence for a direct effect on the proteasome is supported by the experiments in cells that do not express nAChRs and the in vitro functional and binding studies conducted on purified proteasomes. These latter results are consistent with nicotine entering and accumulating in the cell. The concentrations of nicotine in the blood of smokers range from $20 \mathrm{nM}$ to $1 \mu \mathrm{M}$ (Jarvik et al., 2000), but, attributable to its lipophilicity, the brain levels can be three times as high (Gahring and Rogers, 2006). Interestingly, $\left[{ }^{3} \mathrm{H}\right]$ nicotine binding studies conducted on brain homogenates revealed that as much as $50 \%$ of radioactive nicotine cofractionated with the microsomal fractions (Abood et al., 1981). Microsomes, which also cofractionate with the proteasome complex, are the last quality-check station for proteins proceeding to the Golgi compartment (Palmer et al., 1996).

Another important question is whether the effects observed in the PFC occur in other brain areas. Proteasomal components may be different in different areas of the brain (El-Khodor et al., 2001), and there are brain region-specific differences in proteasomal activities (McNaught et al., 2004; Zeng et al., 2005). It is possible that the effects of nicotine depend on the subunit composition of the proteasome and/or the presence of different accessory proteins, an hypothesis supported by the observation that nicotine treatment affects protein levels of proteasomal components and glutamate receptors in a region-specific manner (Kane et al., 2004, 2005). This specificity also applies to known proteasomal inhibitors whose effects on protein degradation can vary significantly because of their ability to modulate cell-specific intracellular pathways (Wojcik, 2002).

\section{Conclusions}

Nicotine can affect brain function by binding to nAChRs and via a newly discovered interaction with the UPS. The interaction with the UPS might underlie the ability of nicotine to both produce addiction and enhance cognition. In addition, because the interaction of nicotine with the UPS does not completely require the presence of nAChRs, our results provide a mechanism for the effects of nicotine on all cells and organ systems.

\section{References}

Abood LG, Reynolds DT, Booth H, Bidlack JM (1981) Sites and mechanisms for nicotine's action in the brain. Neurosci Biobehav Rev 5:479-486.

Ageta H, Kato A, Hatakeyama S, Nakayama K, Isojima Y, Sugiyama H (2001) Regulation of the level of Vesl-1S/Homer-1a proteins by ubiquitinproteasome proteolytic systems. J Biol Chem 276:15893-15897.

Benowitz NL, Kuyt F, Jacob III P (1982) Circadian blood nicotine concentrations during cigarette smoking. Clin Pharmacol Ther 32:758-764.

Bingol B, Schuman EM (2006) Activity-dependent dynamics and sequestration of proteasomes in dendritic spines. Nature 441:1144-1148.

Brookman JL, Stott AJ, Cheeseman PJ, Burns NR, Adams SE, Kingsman AJ, Gull K (1995) An immunological analysis of Tyl virus-like particle structure. Virology 207:59-67.

Buisson B, Bertrand D (2002) Nicotine addiction: the possible role of functional upregulation. Trends Pharmacol Sci 23:130-136.

Burbea M, Dreier L, Dittman JS, Grunwald ME, Kaplan JM (2002) Ubiquitin and AP180 regulate the abundance of GLR-1 glutamate receptors at postsynaptic elements in C. elegans. Neuron 35:107-120.

Chen L, Chetkovich DM, Petralia RS, Sweeney NT, Kawasaki Y, Wenthold RJ, Bredt DS, Nicoll RA (2000) Stargazin regulates synaptic targeting of AMPA receptors by two distinct mechanisms. Nature 408:936-943.

Christianson JC, Green WN (2004) Regulation of nicotinic receptor expression by the ubiquitin-proteasome system. EMBO J 23:4156-4165.

Ciruela F, Soloviev MM, McIlhinney RA (1999) Co-expression of metabo- 
tropic glutamate receptor type 1alpha with homer-1a/Vesl-1S increases the cell surface expression of the receptor. Biochem J 341:795-803.

Colledge M, Snyder EM, Crozier RA, Soderling JA, Jin Y, Langeberg LK, Lu H, Bear MF, Scott JD (2003) Ubiquitination regulates PSD-95 degradation and AMPA receptor surface expression. Neuron 40:595-607.

Collins AC, Evans CB, Miner LL, Marks MJ (1986) Mecamylamine blockade of nicotine responses: evidence for two brain nicotinic receptors. Pharmacol Biochem Behav 24:1767-1773.

Conquet F, Bashir ZI, Davies CH, Daniel H, Ferraguti F, Bordi F, Franz-Bacon K, Reggiani A, Matarese V, Conde F, Collingridge GL, Crepel F (1994) Motor deficit and impairment of synaptic plasticity in mice lacking mGluR1. Nature 372:237-243.

Corringer PJ, Sallette J, Changeux JP (2006) Nicotine enhances intracellular nicotinic receptor maturation: a novel mechanism of neural plasticity? J Physiol (Paris) 99:162-171.

Dajas-Bailador F, Wonnacott S (2004) Nicotinic acetylcholine receptors and the regulation of neuronal signalling. Trends Pharmacol Sci 25:317-324.

Dani JA, Harris RA (2005) Nicotine addiction and comorbidity with alcohol abuse and mental illness. Nat Neurosci 8:1465-1470.

Dantuma NP, Lindsten K, Glas R, Jellne M, Masucci MG (2000) Short-lived green fluorescent proteins for quantifying ubiquitin/proteasomedependent proteolysis in living cells. Nat Biotechnol 18:538-543.

Darsow T, Booker TK, Pina-Crespo JC, Heinemann SF (2005) Exocytic trafficking is required for nicotine-induced up-regulation of alpha 4 beta 2 nicotinic acetylcholine receptors. J Biol Chem 280:18311-18320.

David HM, Lake JR, Victoria AC, Cunningham JS, Kathleen MH, Delia LC, Owen BW (1994) The nicotinic antagonist mecamylamine precipitates nicotine abstinence syndrome in the rat. Psychopharmacology (Berl) 115:180-184.

Davis JA, James JR, Siegel SJ, Gould TJ (2005) Withdrawal from chronic nicotine administration impairs contextual fear conditioning in C57BL/6 mice. J Neurosci 25:8708-8713.

Delibas N, Doguc DK, Sutcu R, Eroglu E, Gokalp O (2005) Effect of nicotine on hippocampal nicotinic acetylcholine alpha7 receptor and NMDA receptor subunits $2 \mathrm{~A}$ and $2 \mathrm{~B}$ expression in young and old rats. Int J Neurosci 115:1151-1163.

Ehlers MD (2003) Activity level controls postsynaptic composition and signaling via the ubiquitin-proteasome system. Nat Neurosci 6:231-242.

Ehrengruber MU, Kato A, Inokuchi K, Hennou S (2004) Homer/Vesl proteins and their roles in CNS neurons. Mol Neurobiol 29:213-227.

El-Khodor BF, Kholodilov NG, Yarygina O, Burke RE (2001) The expression of mRNAs for the proteasome complex is developmentally regulated in the rat mesencephalon. Brain Res Dev Brain Res 129:47-56.

Fenster CP, Whitworth TL, Sheffield EB, Quick MW, Lester RA (1999a) Upregulation of surface $\alpha 4 \beta 2$ nicotinic receptors is initiated by receptor desensitization after chronic exposure to nicotine. J Neurosci 19:4804-4814.

Fenster CP, Hicks JH, Beckman ML, Covernton PJ, Quick MW, Lester RA (1999b) Desensitization of nicotinic receptors in the central nervous system. Ann NY Acad Sci 868:620-623.

Ferrari R, Le Novere N, Picciotto MR, Changeux JP, Zoli M (2002) Acute and long-term changes in the mesolimbic dopamine pathway after systemic or local single nicotine injections. Eur J Neurosci 15:1810-1818.

Gahring LC, Rogers SW (2006) Neuronal nicotinic acetylcholine receptor expression and function on nonneuronal cells. AAPS J 7:E885-E894.

Gaimarri A, Moretti M, Riganti L, Zanardi A, Clementi F, Gotti C (2007) Regulation of neuronal nicotinic receptor traffic and expression. Brain Res Rev 55:134-143.

Gentry CL, Lukas RJ (2002) Regulation of nicotinic acetylcholine receptor numbers and function by chronic nicotine exposure. Current Drug Targets CNS Neurol Disord 1:359-385.

Glickman MH, Ciechanover A (2002) The ubiquitin-proteasome proteolytic pathway: destruction for the sake of construction. Physiol Rev 82:373-428.

Grosshans DR, Clayton DA, Coultrap SJ, Browning MD (2002) LTP leads to rapid surface expression of NMDA but not AMPA receptors in adult rat CA1. Nat Neurosci 5:27-33.

Gurd JW, Jones LR, Mahler HR, Moore WJ (1974) Isolation and partial characterization of rat brain synaptic plasma membranes. J Neurochem 22:281-290.
Hegde AN, DiAntonio A (2002) Ubiquitin and the synapse. Nat Rev Neurosci 3:854-861.

Jarvik ME, Madsen DC, Olmstead RE, Iwamoto-Schaap PN, Elins JL, Benowitz NL (2000) Nicotine blood levels and subjective craving for cigarettes. Pharmacol Biochem Behav 66:553-558.

Ji D, Lape R, Dani JA (2001) Timing and location of nicotinic activity enhances or depresses hippocampal synaptic plasticity. Neuron 31:131-141.

Jones S, Bonci A (2005) Synaptic plasticity and drug addiction. Curr Opin Pharmacol 5:20-25.

Kane JK, Konu O, Ma JZ, Li MD (2004) Nicotine coregulates multiple pathways involved in protein modification/degradation in rat brain. Brain Res Mol Brain Res 132:181-191.

Kane JK, Hwang Y, Konu O, Loughlin SE, Leslie FM, Li MD (2005) Regulation of Homer and group I metabotropic glutamate receptors by nicotine. Eur J Neurosci 21:1145-1154.

Kim E, Sheng M (2004) PDZ domain proteins of synapses. Nat Rev Neurosci 5:771-781.

Kisselev AF, Goldberg AL (2005) Monitoring activity and inhibition of 26S proteasomes with fluorogenic peptide substrates. Methods Enzymol 398:364-378.

Kuryatov A, Luo J, Cooper J, Lindstrom J (2005) Nicotine acts as a pharmacological chaperone to up-regulate human alpha4beta2 acetylcholine receptors. Mol Pharmacol 68:1839-1851.

Levin ED (2002) Nicotinic receptor subtypes and cognitive function. J Neurobiol 53:633-640.

Liu L, Wong TP, Pozza MF, Lingenhoehl K, Wang Y, Sheng M, Auberson YP, Wang YT (2004) Role of NMDA receptor subtypes in governing the direction of hippocampal synaptic plasticity. Science 304:1021-1024.

Losi G, Prybylowski K, Fu Z, Luo J, Wenthold RJ, Vicini S (2003) PSD-95 regulates NMDA receptors in developing cerebellar granule neurons of the rat. J Physiol (Lond) 548:21-29.

Lynch MA (2004) Long-term potentiation and memory. Physiol Rev 84:87-136.

Malenka RC, Nicoll RA (1999) Long-term potentiation-a decade of progress? Science 285:1870-1874.

Malik B, Schlanger L, Al-Khalili O, Bao HF, Yue G, Price SR, Mitch WE, Eaton DC (2001) Enac degradation in A6 cells by the ubiquitin-proteosome proteolytic pathway. J Biol Chem 276:12903-12910.

Malinow R, Malenka RC (2002) AMPA receptor trafficking and synaptic plasticity. Annu Rev Neurosci 25:103-126.

Mansvelder HD, McGehee DS (2000) Long-term potentiation of excitatory inputs to brain reward areas by nicotine. Neuron 27:349-357.

McNaught KS, Perl DP, Brownell AL, Olanow CW (2004) Systemic exposure to proteasome inhibitors causes a progressive model of Parkinson's disease. Ann Neurol 56:149-162.

Mimnaugh EG, Bonvini P, Neckers L (1999) The measurement of ubiquitin and ubiquitinated proteins. Electrophoresis 20:418-428.

Newhouse PA, Potter A, Singh A (2004) Effects of nicotinic stimulation on cognitive performance. Curr Opin Pharmacol 4:36-46.

Palmer A, Rivett AJ, Thomson S, Hendil KB, Butcher GW, Fuertes G, Knecht E (1996) Subpopulations of proteasomes in rat liver nuclei, microsomes and cytosol. Biochem J 316:401-407.

Patrick GN, Bingol B, Weld HA, Schuman EM (2003) Ubiquitin-mediated proteasome activity is required for agonist-induced endocytosis of GluRs. Curr Biol 13:2073-2081.

Peng X, Gerzanich V, Anand R, Wang F, Lindstrom J (1997) Chronic nicotine treatment up-regulates alpha3 and alpha7 acetylcholine receptor subtypes expressed by the human neuroblastoma cell line SH-SY5Y. Mol Pharmacol 51:776-784.

Powers M, Days E, Gahring L, Rogers S (2005) Nicotinic receptor modulation of glutamate receptor expression in the mouse brain. Soc Neurosci Abstr 31:723.23.

Sallette J, Pons S, Devillers-Thiery A, Soudant M, Prado de Carvalho L, Changeux JP, Corringer PJ (2005) Nicotine upregulates its own receptors through enhanced intracellular maturation. Neuron 46:595-607.

Sawada S, Yamamoto C, Ohno-Shosaku T (1994) Long-term potentiation and depression in the dentate gyrus, and effects of nicotine. Neurosci Res 20:323-329.

Vallejo YF, Buisson B, Bertrand D, Green WN (2005) Chronic nicotine exposure upregulates nicotinic receptors by a novel mechanism. J Neurosci 25:5563-5572.

Wang F, Nelson ME, Kuryatov A, Olale F, Cooper J, Keyser K, Lindstrom J 
(1998) Chronic nicotine treatment up-regulates human alpha3 beta2 but not alpha3 beta4 acetylcholine receptors stably transfected in human embryonic kidney cells. J Biol Chem 273:28721-28732.

Wang F, Chen H, Steketee JD, Sharp BM (2007) Upregulation of ionotropic glutamate receptor subunits within specific mesocorticolimbic regions during chronic nicotine self-administration. Neuropsychopharmacology 32:103-109.

Welsby P, Rowan M, Anwyl R (2006) Nicotinic receptor-mediated enhancement of long-term potentiation involves activation of metabotropic glutamate receptors and ryanodine-sensitive calcium stores in the dentate gyrus. Eur J Neurosci 24:3109-3118.

Wojcik C (2002) Regulation of apoptosis by the ubiquitin and proteasome pathway. J Cell Mol Med 6:25-48.

Wu X, Yen L, Irwin L, Sweeney C, Carraway III KL (2004) Stabilization of the E3 ubiquitin ligase Nrdp1 by the deubiquitinating enzyme USP8. Mol Cell Biol 24:7748-7757.

Yamashita M, Shinnakasu R, Asou H, Kimura M, Hasegawa A, Hashimoto K, Hatano N, Ogata M, Nakayama T (2005) Ras-ERK MAPK cascade regulates GATA3 stability and Th2 differentiation through ubiquitinproteasome pathway. J Biol Chem 280:29409-29419.

Yan FF, Lin CW, Cartier EA, Shyng SL (2005) Role of ubiquitin-proteasome degradation pathway in biogenesis efficiency of $\beta$-cell ATP-sensitive potassium channels. Am J Physiol Cell Physiol 289:C1351-C1359.

Yi JJ, Ehlers MD (2007) Emerging roles for ubiquitin and protein degradation in neuronal function. Pharmacol Rev 59:14-39.

Zeng BY, Medhurst AD, Jackson M, Rose S, Jenner P (2005) Proteasomal activity in brain differs between species and brain regions and changes with age. Mech Ageing Dev 126:760-766. 